\title{
Observação e registro das fases da lua: uma experiência na formação continuada de professores
}

Kaleb Ribeiro Alho ${ }^{1}$

Secretaria de Educação do Estado de Minas Gerais

Itajubá - MG

Newton Figueiredo ${ }^{1}$

João Ricardo Neves da Silval

Instituto de Física e Química - Universidade Federal de Itajubá

Itajubá - MG

\section{Resumo}

De todos os fenômenos astronômicos ao alcance do olho humano, um dos mais notáveis e acessíveis à observação, nos diferentes lugares do planeta, são as Fases da Lua. No entanto, diversos estudos apontam a existência deficiências no processo de ensino aprendizagem dos conteúdos de Astronomia incluindo esse fenômeno tão cotidiano. Esse trabalho faz um relato analítico de uma proposta para o ensino das fases lunares no âmbito da Formação Continuada de Professores por meio de uma atividade prática cujo objetivo foi enriquecer o processo de formação continuada para o ensino de Astronomia. A atividade baseiase num recurso observacional que possibilita a aquisição e a construção de conhecimentos do fenômeno estudado. São apresentados aqui elementos de trabalho colaborativo e de construção de conceitos astronômicos de professores da educação básica em processo de elaboração de uma atividade didática sobre as Fases da Lua.

Palavras-chave: Ensino de Astronomia; Fases da Lua; Calendário Lunar; Formação Continuada de Professores.

\footnotetext{
${ }^{+}$Observing and recording moon phases: an in-service teacher training activity

* Recebido: 29 de junho de 2020. Aceito: 30 de abril de 2021.

${ }^{1}$ E-mails: kalebalhofisica@gmail.com; newton@unifei.edu.br; jricardo.fisica@unifei.edu.br
} 


\begin{abstract}
Of all the astronomical phenomena within reach of the human eye, one of the most remarkable and accessible to observation, in the different places of the planet, are the Phases of the Moon. However, several studies point to the existence of deficiencies in the teaching process learning the contents of Astronomy including this phenomenon so daily. This work makes an analytical report of a proposal for the teaching of lunar phases in the context of Continuing Teacher Training through a practical activity whose objective was to enrich the process of continuous formation for the teaching of Astronomy. The activity is based on an observational resource that allows the acquisition and construction of knowledge of the studied phenomenon. The elements of collaborative work and construction of astronomical concepts of basic education teachers in the process of elaborating a didactic activity on the Phases of the Moon are presented here.
\end{abstract}

Keywords: Astronomy Education; Phases of the Moon; Lunar Calendar; In-service Teacher Training.

\title{
I. Introdução
}

Os conhecimentos astronômicos deram às civilizações os meios para subsidiar a própria sobrevivência, como, por exemplo, a marcação precisa da passagem do tempo, o que possibilitou uma maior sistematização do sistema de agricultura e a previsão de temporadas de frio e calor. Além disso, os fenômenos celestes sempre impressionaram o homem, quer por sempre terem lhe sido úteis em sua vida prática, quer pela sua interpretação sobrenatural (MICHA, 2018).

A Lua é o objeto astronômico mais próximo de nós e o mais brilhante depois do Sol. Desde os tempos mais remotos é importante referência cultural nos mais diversos ramos da atividade humana, e a regularidade de seu ciclo de fases serviu de base para a medição do tempo e para a construção de calendários (SARAIVA; SIVEIRA; STEFFANI, 2011).

Mesmo com os avanços científicos e tecnológicos e com o acúmulo de conhecimentos científicos sobre estes fenômenos, a crença de que os fenômenos celestes podem de alguma forma influenciar ou estarem ligados com os acontecimentos da Terra de uma forma sobrenatural ou desconhecida ainda está arraigada na sociedade humana (MICHA, 2018).

Como os modelos científicos sobre os fenômenos astronômicos só vão começar a ser introduzidos na escolaridade básica, mais comumente no ensino fundamental, é muito comum que as pessoas tenham concepções, muitas vezes de senso comum, coexistindo com 
conhecimentos científicos, dando ao mesmo sujeito duas visões diferentes sobre o mesmo assunto. Nesse sentido, a pessoa cria sua própria forma de explicar o universo e fatos do cotidiano associados aos eventos astronômicos. É interessante notar, porém, que os conhecimentos científicos que se vai ganhando ao longo da vida não são capazes de substituir completamente os conceitos construídos preliminarmente, o que acaba por gerar muita confusão (MICHA, 2018).

Na direção da criação de uma unidade nos conteúdos curriculares de Astronomia a serem apresentados na educação básica nacional, a Base Nacional Comum Curricular (BRASIL, 2018) documento mais recente da educação brasileira, reconhece e recomendam que os assuntos a ela relacionados devem ser apresentados nas disciplinas de Ciências e de Física respectivamente nos ensinos fundamental e médio, podendo ainda serem abordados em outras disciplinas tendo em vista que os conteúdos de Astronomia são interdisciplinares.

Embora exista uma grande difusão de concepções de senso comum referentes aos fenômenos astronômicos presentes nos discursos de alunos e professores, talvez, o maior obstáculo ainda sejam os limitados conhecimentos de Astronomia de docentes que trabalham com esses temas na educação básica, tendo em vista uma formação inicial deficiente na área de Astronomia. Langhi e Nardi (2011) apontam que boa parte dos professores não aprenderam Astronomia ao longo de sua graduação, porque ela não costuma ser uma disciplina obrigatória nos cursos de formação.

Devido a uma formação inicial carente em tópicos de Astronomia Bretones, (1999) enfatiza a existência de uma insegurança por parte dos professores em abordá-la, levando-os a evitarem assuntos que a rementem em sala de aula.

Apesar dos problemas anteriormente citados, Kantor (2001) enfatiza que a Astronomia pode ser um tema com grande potencial para desenvolver a capacidade de observação, análise e interpretação de fenômenos naturais, uma vez que alguns fenômenos astronômicos são de livre acesso à observação. $O$ desenvolvimento destas capacidades potencializa-se com a construção de atividades práticas. Assim, o estudo dos astros pode ser realizado sem instrumentos sofisticados, já que podemos observar alguns fenômenos a olho nu, mesmo estes se encontrando a grandes distâncias, tornando-se o céu um "laboratório" astronômico (LANGHI, 2011).

Desta forma, emerge das aulas de Astronomia na educação básica a necessidade de atividades que favoreçam o desenvolvimento, construção e a assimilação de conceitos que permitam que os fenômenos celestes sejam observados e entendidos à luz da ciência. Para este fim, são necessárias estratégias de ensino que propiciem um correlacionar da teoria com o cotidiano, que permita entender o conhecimento como um processo de construção permeado pela curiosidade e pela criatividade humana.

Neste trabalho, fazemos um relato de uma atividade prática realizada no contexto de um de curso de formação continuada estruturado e construído de forma colaborativa entre professores da educação básica de escolas rurais do Sul de Minas Gerais e três pesquisadores 
do campo de educação em ciências. Os dados constituem-se das observações, registros, discursos e diálogos entre professores e instrutores produzidos durante o curso.

A atividade didática buscou apresentar este conteúdo de forma prática por meio de um recurso observacional permitindo ao docente correlacionar a teoria com o cotidiano e em contra partida enriquecer os conhecimentos dos mesmos sobre as fases da Lua.

\section{Considerações científicas sobre as fases da Lua}

De todos os fenômenos astronômicos ao alcance do olho humano, um dos mais notáveis e acessíveis à observação, nos diferentes lugares do planeta Terra, são as fases da Lua (COSTA, 2011). As fases lunares, que constituem um dos fenômenos astronômicos mais comuns à observação da maioria das pessoas, foram explicadas por Aristóteles há mais de 300 anos antes da era cristã, sendo um dos conhecimentos mais antigos e básicos da ciência (SARAIVA; SILVEIRA; STEFFANI, 2011).

A Lua é um satélite natural do nosso planeta e está cerca de 384 mil quilômetros de distância da Terra. Considerada um corpo frio, ela não possui luz própria. A luminosidade que parte da superfície lunar é provocada substancialmente pela reflexão da luz solar, e sua intensidade é praticamente irrelevante em termos da influência que poderia exercer sobre o nosso planeta. Como os raios solares chegam à Lua aproximadamente paralelos, devido à distância Sol-Lua, apenas uma de suas metades fica iluminada, como mostra a Fig. 1.

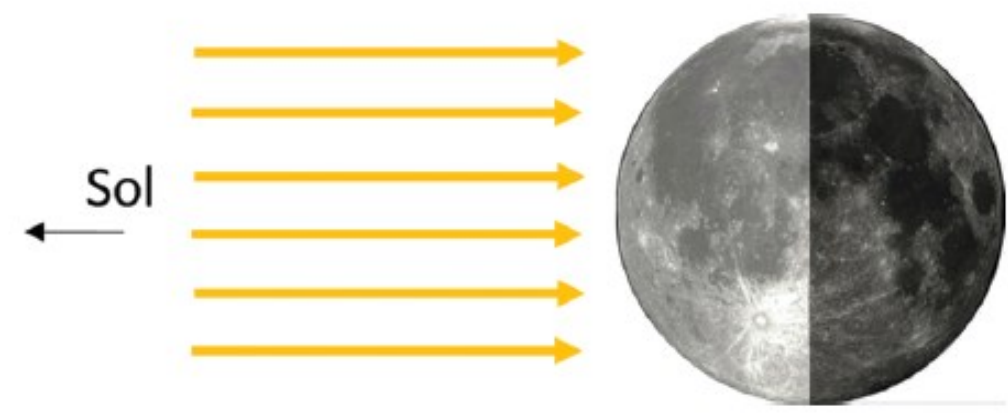

Fig. 1 - Diagrama de raios luminosos representando a iluminação da Lua pelo Sol. Fonte: Micha (2018).

Em todos os meses a Lua exibe um ciclo de formatos que passam pelo completamente visível, o invisível, e estágios intermediários entre estes, nos quais podemos vê-la ora mais, ora menos iluminada. Sabemos que isso se deve as posições relativas entre Lua-Terra-Sol.

A cada dia o Sol ilumina a Lua sob um ângulo diferente, à medida que ela se desloca em torno da Terra. Desta forma, em cada dia da lunação pode-se visualizar o satélite um pouco diferente. De forma rigorosa, cada fase lunar representa um ângulo cujo vértice está na Terra, entre Lua e Sol. Como a Lua se move, esse ângulo muda constantemente. Assim, pode- 
se dizer que a Lua tem infinitas fases.

A face iluminada da Lua é aquela que está voltada para o Sol. Já a fase da Lua representa o quanto dessa face iluminada pelo Sol está voltada também para a Terra. Tradicionalmente apenas as quatro principais fases da Lua (Nova, Quarto-Crescente, Cheia e Quarto-Minguante) recebem nomes. As fases ocorrem nessa ordem durante um mês sinódico ou lunação, cuja duração é de aproximadamente 29,5 dias.

Dessa forma, ao longo de um período sinódico ${ }^{2}$, vemos a Lua mudar da fase Nova na qual a face que está sendo iluminada não aparece visível para a Terra (posição 1 na órbita representada na Fig. 2) para a fase Crescente, na qual a face que está sendo iluminada começa a aparecer e vai aumentando com o tempo para os observadores da Terra, passando pela fase Cheia, aonde a face iluminada está completamente virada para a Terra (posição 3 na órbita representada na Fig. 2), chegando, por fim, na fase Minguante, na qual sua face iluminada vai reduzindo de tamanho até sumir completamente ao final do ciclo. As posições 2 e 4 da órbita representada na Fig. 2 representam os Quartos Crescente e Minguante, respectivamente (GHEZZI E RUGGLES; 2007).

Para um observador na Terra, a Lua gira ao redor do planeta como representado pela circunferência pontilhada na Fig. 2.

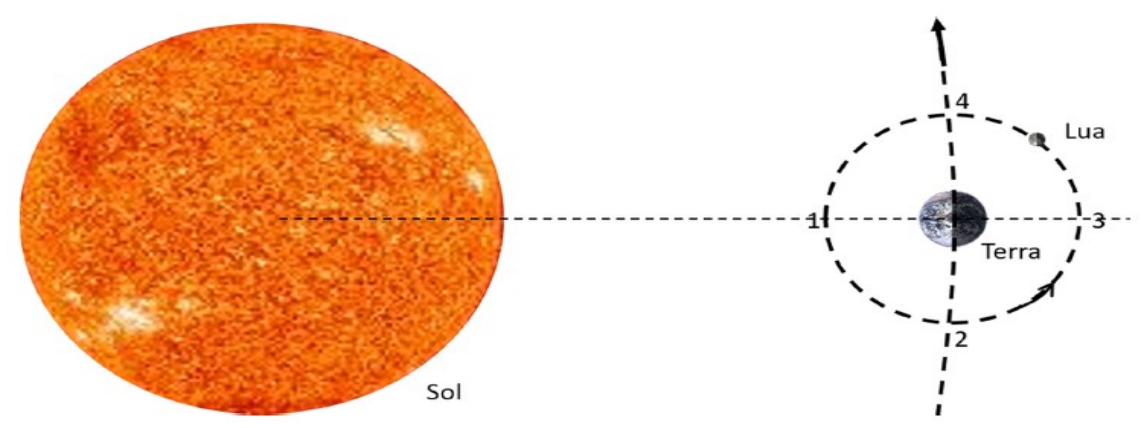

Fig. 2 - Esquema ilustrativo fora de escala do sistema Sol-Terra-Lua visto de um plano superior paralelo ao da órbita da Terra em torno do Sol (curva aberta pontilhada). Alinha pontilhada fechada indica a órbita da Lua vista por um observador da Terra. Fonte: Micha (2018).

As Fig. 3a e 3b mostram a órbita acoplada do nosso planeta e da Lua ao redor do Sol e o aspecto visível da Lua para um observador na Terra especificamente nas fases Nova e Cheia (Posições 1 e 3 da Fig. 2). Nessas fases, ignorando o fato de que o plano da órbita lunar não coincide com a eclíptica, o sistema Sol-Terra-Lua encontra-se alinhado.

\footnotetext{
2 É o intervalo de tempo decorrido entre duas configurações iguais consecutivas. Neste caso, trata-se do período de revolução aparente da Lua, em relação à Terra.
} 

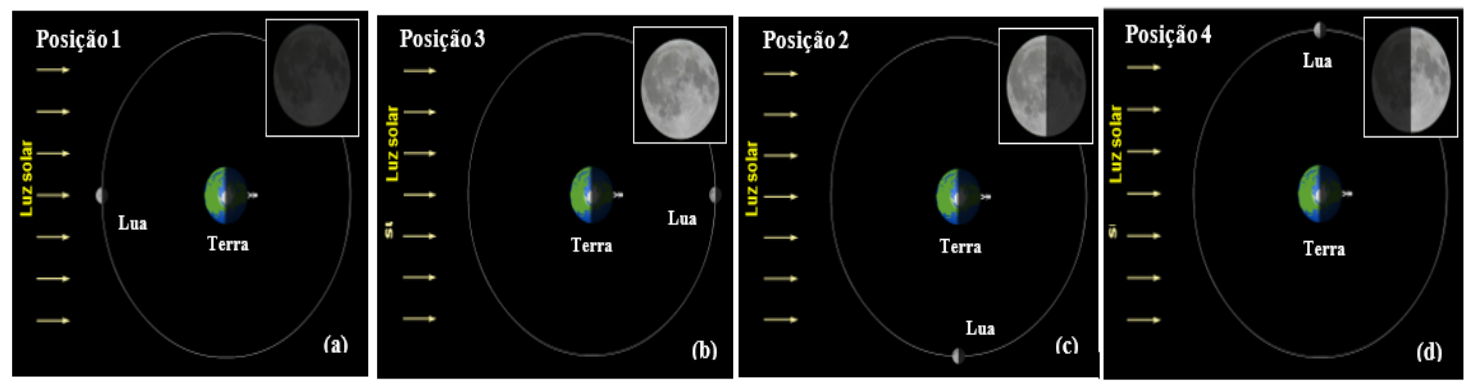

Fig. 3 - A figura (3a e 3b) mostra a posição do sistema Sol-Terra-Lua para as fases Nova e cheia da Lua. A figura (3c e 3d) mostra a posição do sistema Sol-Terra-Lua nas fases Quarto-Crescente e Quarto-Minguante da Lua. Fonte: Autores.

Já as Fig. 3c e 3d mostram a posição e o aspecto visível da Lua nas fases QuartoCrescente e Quarto-Minguante (Posições 2 e 4, Fig. 2). Nessas fases o sistema Sol-Terra-Lua forma um ângulo de $90^{\circ}$ entre si.

Apesar de verem a mesma fase independente da longitude, observadores ao redor do globo terrestre em diferentes latitudes percebem uma ligeira diferença na forma com a qual a Lua se apresenta no céu (MICHA, 2018). A Fig. 4 ilustra, de maneira geral, essa mudança de perspectiva. Se tomarmos o Sul como referência, podemos dizer que os observadores do Hemisfério Norte estão "de cabeça para baixo" no planeta e, por isso, verão a Lua em formato invertido daquele observado no Sul. Dessa forma, quando veem a Lua em forma de " $D$ " no Quarto Crescente, os observadores do hemisfério Sul a veem em forma de "C" e vice-versa para Quarto Minguante. Nas fases Nova e Cheia não se percebe diferença no formato, uma vez que a Lua aparece completamente sombreada ou iluminada.
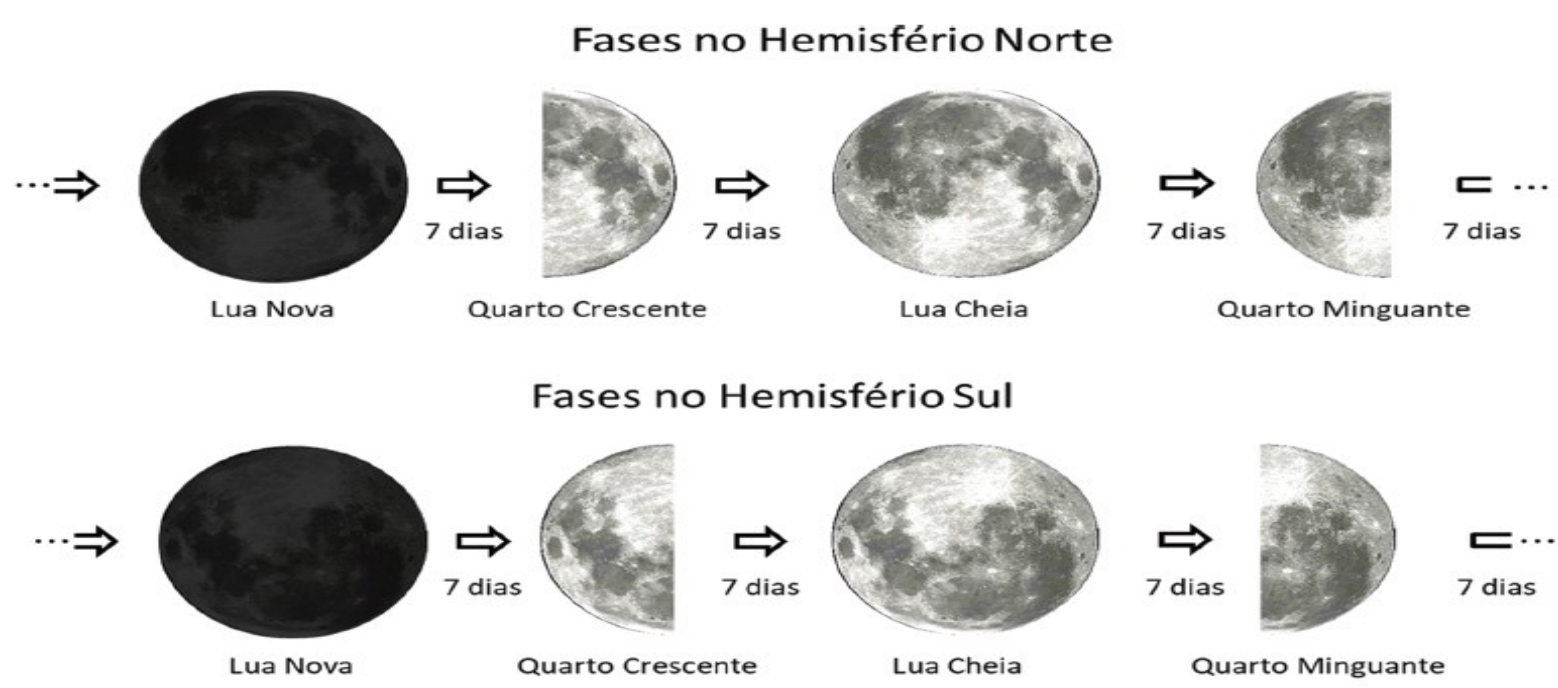

Fig. 4 - Representação das fases da Lua nos Hemisférios. Fonte: Micha (2018). 
Contudo, nem todos os observadores no mesmo hemisfério veem a Lua com a mesma aparência. $O$ ângulo com o qual ela se apresenta no céu depende fortemente da latitude do observador e do horário de observação. Na Fig. 5a, cinco posições terrestres são destacadas a fim de apontar as diferenças na forma observada da Lua.

(a)
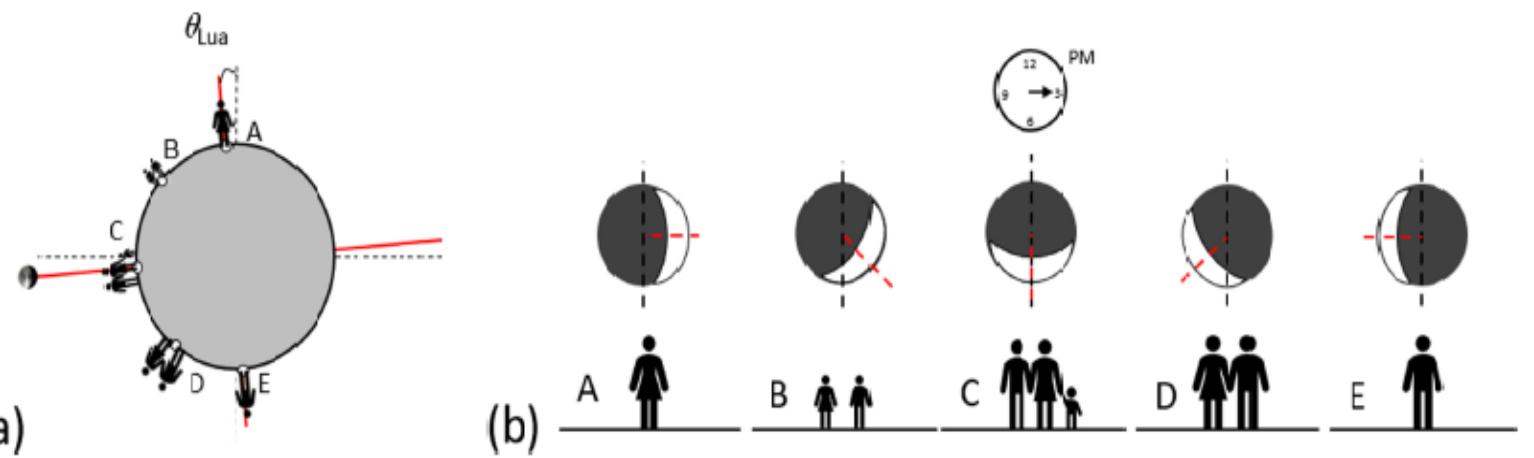

Fig. 5 - Representação da observação da Lua em diferentes pontos da superfície terrestre. São apresentadas, em (a), as posições $A, B, C, D$ e E dos observadores e, em (b), como seria a forma da Lua vista a partir da superficie nos mesmos pontos. Fonte: Micha (2018).

A observadora em A está posicionada em um ponto da Terra cuja vertical local forma $90^{\circ}$ com a direção da Lua. Dessa forma, ela vê a porção iluminada da Lua formando um ângulo de $90^{\circ} \mathrm{com}$ a vertical, como representado na Fig. 5b. O observador em E está em um ponto diametralmente oposto a $\mathrm{A}$ e, por isso, vê a porção iluminada da Lua no lado oposto, ou seja, a $-90^{\circ}$ com a vertical. Os observadores em $\mathrm{C}$ se encontram em um ponto cuja vertical local está paralela à direção da Lua. Por esse motivo, veem a Lua de uma posição neutra, formando $0^{\circ}$ (ou $180^{\circ}$ dependendo da época do ano) com a vertical. Os observadores em B se encontram em uma posição mediana entre A e C e devem ver a Lua girada de um ângulo entre $0^{\circ}$ e $90^{\circ}$ com a vertical. Já os observadores em $\mathrm{D}$, que se encontram entre $\mathrm{C}$ e $\mathrm{E}$ devem ver a Lua em um ângulo entre $0^{\circ} \mathrm{e}-90^{\circ}$ com a vertical (MICHA, 2018).

Como a porção que vemos iluminada da Lua varia de dia para dia os astrônomos definem suas fases em termos de número de dias decorridos desde a Lua Nova (de 0 a 29,5) em termos de fração iluminada da face visível (0\% a 100\%).

A Fig. 6 apresenta uma típica ilustração utilizada para explicar as fases da Lua. A figura apresenta o sistema Sol-Terra-Lua como seria visto por um observador externo olhando diretamente para o polo sul da Terra. O círculo externo mostra a Lua em diferentes posições relativas em relação à linha Sol-Terra, assumidas à medida que ela orbita a Terra de oeste para leste (sentido horário para um observador olhando para o polo sul). O círculo interno mostra as formas aparentes da Lua, em cada situação, para um observador no hemisfério sul da Terra. 


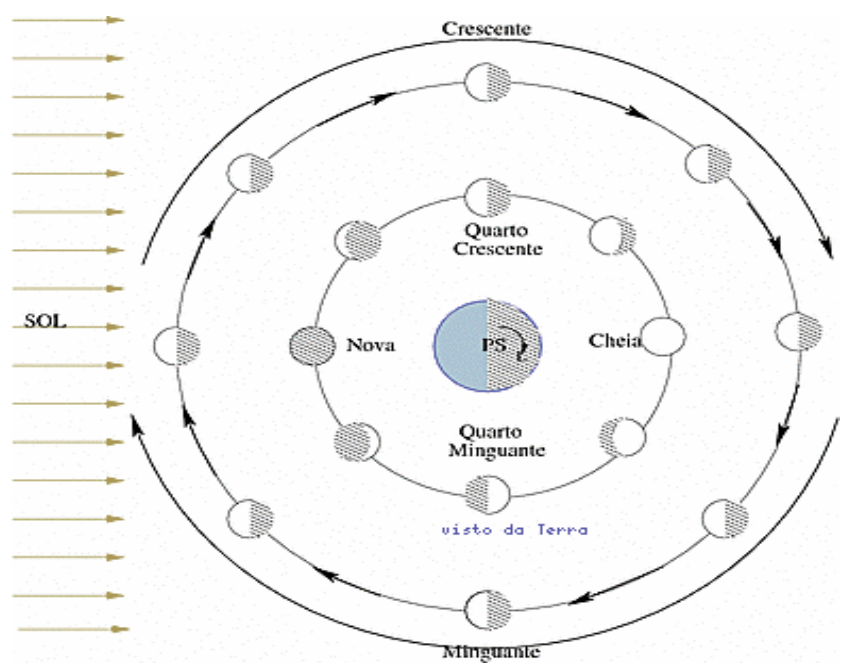

Fig. 6 - Lua em órbita circular em torno da Terra. Visão de um observador externo a Terra olhando para o polo sul terrestre. Fonte: UFRGS $S^{3}$.

Entretanto, existem dois aspectos importantes sobre o movimento da Lua que não são mostrados na Fig. 4. O primeiro é que o plano da órbita da Lua em torno da Terra está inclinado $5^{\circ}$ em relação ao plano da à orbita da Terra em torno do Sol (eclíptica) como mostra a Fig. 7.

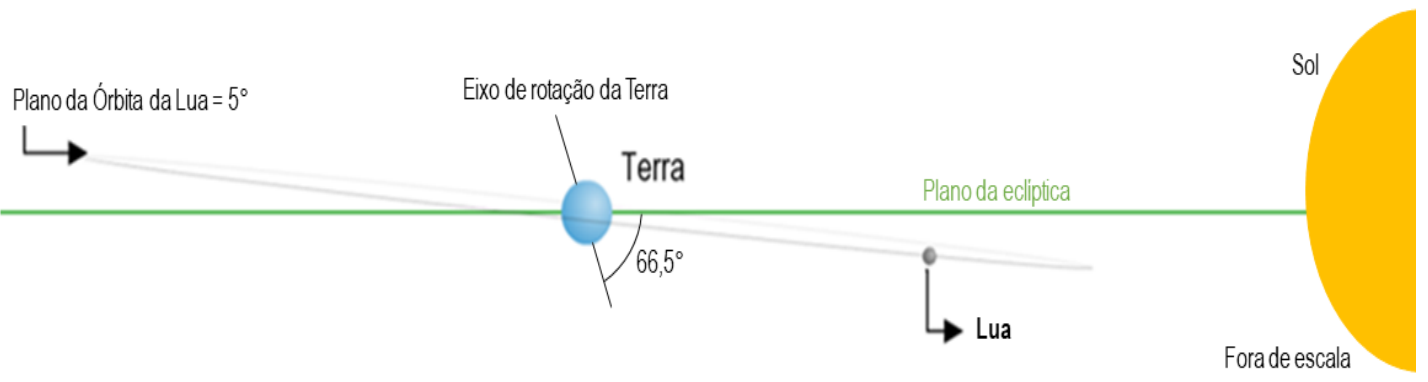

Fig. 7 - Plano da órbita da Lua e a eclíptica. Fonte: Autores.

Esta inclinação interfere na ocorrência dos eclipses. Um eclipse acontece sempre que um corpo entra na sombra de outro. Assim, quando a Lua em sua fase Cheia entra na sombra da Terra, acontece um eclipse lunar. Quando a Terra é atingida pela sombra da Lua em sua fase Nova, acontece um eclipse solar. Portanto só ocorrem eclipses quando a Lua está na fase Cheia ou Nova. Entretanto, para que a Lua entre na sombra da Terra e vice-versa é necessário que ocorra o alinhamento entre os três astros (Sol-Terra-Lua), todavia, por conta da inclinação entre os planos das órbitas, o alinhamento dos três astros (condição necessária para ocorrência de eclipses) é prejudicado na maior parte do ano.

O segundo é que o movimento de rotação da Lua em torno do próprio eixo é sincronizado com seu movimento de revolução ao redor da Terra (Fig. 8). Isso indica que

\footnotetext{
${ }^{3}$ Disponível em: <http://astro.if.ufrgs.br/lua/lua.htm>.
} 
esses movimentos possuem o mesmo período. Além disso, essa sincronia mantém sempre a mesma face da Lua voltada para a Terra. Isso significa que na Terra sempre vemos a mesma face da Lua no céu.

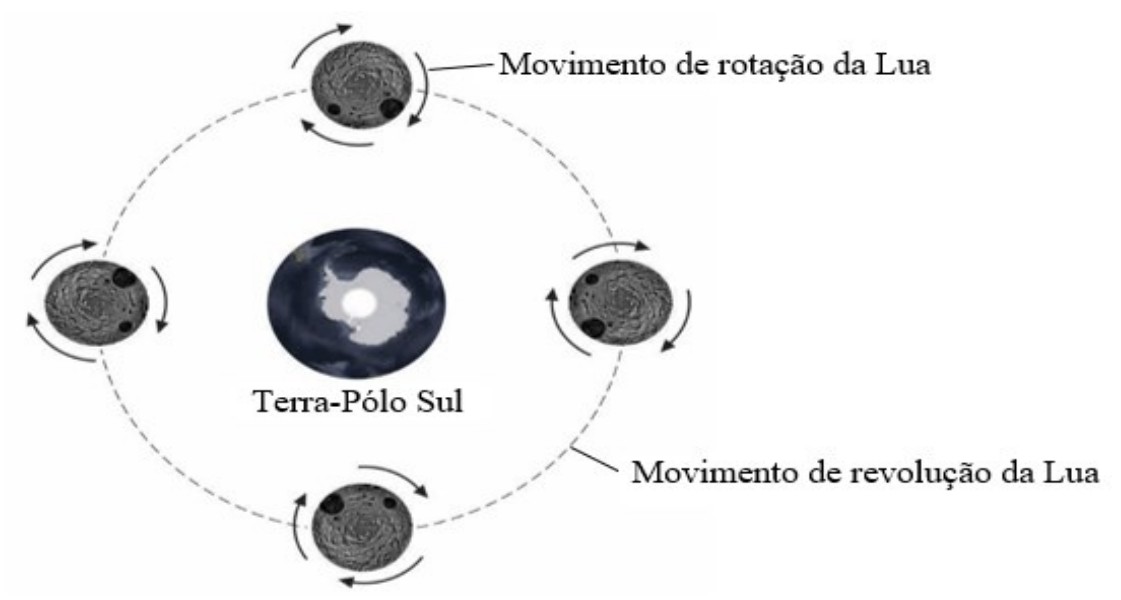

Fig. 8 - Como o movimento de rotação da Lua em torno do seu próprio eixo é sincronizado com o seu movimento de revolução ao redor da Terra, a Lua sempre mantém a mesma face voltada para nosso planeta.

Fonte: Adaptada de <http://astro.if.ufrgs.br/lua/lua.htm>.

\section{Atividades práticas na formação continuada de professores}

Segundo a BNCC (2018), será necessária uma revisão da formação inicial e continuada dos professores para alinhá-las às novas orientações e normativas propostas pelo documento. Além disso, na área de Ciências da Natureza, especificamente na unidade temática Terra e Universo onde encontram-se os conteúdos relativos à Astronomia para a educação básica, a BNCC enfatiza que com a apresentação dos conteúdos dessa unidade ampliam-se experiências de observação do céu, bem como de observação dos principais fenômenos celestes.

$\mathrm{Na}$ mesma direção da nova Base Nacional Comum Curricular, as pesquisas no campo da educação em Astronomia no país já apontavam para esse caminho. Nos últimos anos uma crescente variedade de trabalhos foram publicados com o objetivo de auxiliar na implementação e no ensino dos conteúdos de Astronomia na educação básica, bem como em propostas de ações de formação continuada voltadas para a prática do professor, na abordagem de conteúdos, apresentação de metodologias alternativas, aplicação de atividades práticas e na construção de materiais pedagógicos voltados para o processo de ensino e aprendizagem da área, como exemplo podemos citar trabalhos como os de Rogério e Bisch (2018), Spina (2018), Oliveira, Moreau e Barros (2014), Dottori (2003), Prado e Nardi (2020), Canalle (1999). 
Além disso, em um mapeamento realizado por Sanzovo et al. (2020) sobre as principais estratégias metodológicas utilizadas na formação de professores de Ciências para o ensino de Astronomia, revelou que há uma diversidade de estratégias de ensino voltadas para o ensino de Astronomia citadas pelos pesquisadores, destacando-se: o uso de modelos $3 \mathrm{~d}$ e/ou práticas de ensino e observação do céu, estratégias não formal de ensino, produção de material didático, atividades investigativas, aulas expositivas, uso de dramatizações e materiais lúdicos além da utilização de propostas de grupos de pesquisa e ensino crítico.

Muitas dessas ações buscam atenuar as lacunas deixadas pela formação inicial dos professores que ensinam os conteúdos de Astronomia na educação básica. Para alguns pesquisadores, a grande variedade de trabalhos científicos publicados nas áreas de ensino de Física e de Ciências revela o interesse e o esforço da comunidade científica em prol do desenvolvimento do ensino de Astronomia no Brasil.

São exemplos desse esforço: a criação da Olimpíada Brasileira de Astronomia e Astronáutica (OBA) em 1998; a Revista Latino-Americana de Educação em Astronomia (RELEA) em 2004, os Encontros Regionais de Ensino de Astronomia (EREAs) em 2009, o Simpósio Nacional de Educação em Astronomia (SNEA) em 2011 e os Encontros Brasileiros de Ensino de Astronomia (EBEA). Também podemos citar o Encontro Nacional de Pesquisa em Educação em Ciências (ENPEC), o Encontro de Pesquisa em Ensino de Física (EPEF) e o Simpósio Nacional de Ensino de Física (SNEF). Além dos encontros da Sociedade Astronômica Brasileira (SAB) e do Encontro Nacional de Astronomia (ENAST), que são encontros mais específicos do campo da Astronomia no país.

Apesar disso, ainda há um distanciamento relevante entre os resultados e indicadores obtidos nas pesquisas e a prática do professor em sala de aula. Esse aspecto foi evidenciado na pesquisa de Gonzatti et al. (2013), na qual nenhum dos professores entrevistados disseram utilizar ou consultar artigos ou periódicos que abordem propostas didáticas ou concepções em Astronomia como subsídio para as suas aulas.

Segundo Pedro et al. (2015), há grande queixa por parte dos professores da escola básica é que os conhecimentos produzidos pela universidade demoram muito a chegar a eles e, quando chegam, são implementados de maneira vertical, sem maiores discussões, desconsiderando a realidade escolar. Além disso, os processos de formação docente que visam propagar estes conhecimentos pouco contribuem para a prática pedagógica, uma vez que as necessidades formativas imediatas dos professores não são consideradas.

Para Langhi e Nardi (2010), é importante que futuras elaborações de programas de formação continuada para professores na área de Astronomia, norteiem-se em resultados de pesquisa da área, do ensino de ciências e da formação de professores, o que poderá proporcionar processos formativos docentes adequados às reais necessidades dos professores.

Em um cenário de necessidade de formação centrada nas necessidades do professor, emergem as atividades práticas. É recorrente na literatura a importância que os professores dão a tais atividades, porém sem levar em consideração toda a gama de possibilidades que 
elas podem oferecer no desenvolvimento de sua prática pedagógica (GALIAZZI et al. 2001) A definição do que seria uma atividade prática não é consensual na literatura, no entanto, neste trabalho adotaremos a definição de Andrade e Massabni (2011) que concebem atividade prática como aquela tarefa educativa que requer do estudante (neste caso do professor) a experiência direta com o material presente fisicamente, com o fenômeno e/ou com dados brutos obtidos do mundo natural ou social, ou seja, o professor deve ter contato direto com o objeto, seja por meio de uma demonstração realizada ou manipulanda.

Para os autores, o importante, é que se apresente o objeto materialmente ao aluno de modo que ele seja capaz de agir sobre o mesmo ou elaborá-lo mentalmente a partir de observações, ou seja, a experiência física deve ocorrer para que o estudante tenha condições de abstrair do fenômeno estudado. Além disso, entende-se que a atividade prática não se deve constituir apenas em atividade mecânica de medição, observação, descrição, entre outras, sem que se extraiam dela "lições" sobre o objeto estudado (ANDRADE; MASSABNI, 2011).

Procuramos neste trabalho, relatar e abordar a relação das possibilidades de aprendizagem e de construção de conhecimentos astronômicos dos professores a partir da proposta de uma atividade prática na perspectiva da produção colaborativa na qual são trabalhadas a observação e o registro das fases da Lua com docentes que lecionam os conteúdos de Astronomia na educação básica.

\section{III.1 O professor participativo na própria formação}

Segundo Schon (2000), os cursos para professores são feitos "para" e não "com" os professores. Nesse modelo de curso, supõe-se mesmo que indiretamente a existência de uma superioridade do conhecimento teórico sobre os saberes práticos. Assim, é importante ter em mente que os cursos para professores ocorrem em ambientes muito diferentes de suas escolas, de suas salas de aula, da sua realidade profissional. Para Gouveia (1992, p. 240):

Os professores têm como atividade prioritária na vida cotidiana o trabalho (ação docente) e não só estudo. Inútil, pois, querer transplantar para os cursos de capacitação programas de estudo que não sejam adequados às suas obrigações docentes diárias. É preciso criar programas que levem em conta a realidade, o cotidiano.

Por isso, é importante que o professor tenha autonomia e espaço de atuação sobre seu processo formativo, participando efetivamente da formulação e estruturação dos cursos, dando sugestões para os conteúdos e apontando estratégias adequadas. Para Maldaner (2000, p. 25):

Os processos de formação continuada já testados e que podem dar respostas positivas têm algumas características relevantes: os grupos de professores que decidem 'tomar nas próprias mãos' o tipo de aula e o conteúdo que irão ensinar, tendo a orientação maior - parâmetros curriculares por exemplo - como referência 
e não como fim; a prevalência dos coletivos organizados sobre individuos isolados como forma de ação, a interação com professores universitários, envolvidos e comprometidos com a formação de novos professores; o compromisso das escolas com a formação continuada de seus professores e com a formação de novos professores compartilhando seus espaços e conquistas.

Para Maldaner (1997, p. 11), nesta nova proposta, que leva em consideração a efetiva participação do professor no seu processo de formação, existem algumas condições iniciais para que a parceria colaborativa ocorra de forma adequada. São elas:

1) que haja professores disponíveis e motivados para iniciar um trabalho reflexivo
conjunto e dispostos a conquistar o tempo e o local adequados para fazê-los; 2) que
a produção científico-tecnológica se dê sobre a atividade dos professores, sobre as
suas práticas e seu conhecimento na ação, sendo as teorias pedagógicas a
referência e não o fim; 3) que os meios e os fins sejam definidos e redefinidos
constantemente no processo e de dentro do grupo; 4) que haja compromisso de
cada membro com o grupo; 5) que a pesquisa do professor sobre a sua atividade se
torne, com o tempo, parte integrante de sua atividade profissional e se justifique
primeiro para dentro do contexto da situação e, secundariamente, para outras
esferas; 6) que se discuta o ensino, a aprendizagem, o ensinar, e o aprender da
ciência, ou de outras áreas do conhecimento humano, que cabe à escola
proporcionar aos alunos, sempre referenciado às teorias e concepções
recomendadas pelos avanços da ciência pedagógica comprometida com os atores
do processo escolar e não com as políticas educacionais exógenas; 7) que os
professores universitários envolvidos tenham experiência com os problemas
concretos das escolas e consigam atuar dentro do componente curricular objeto de
mudança, que pode ser interdisciplinar ou de disciplina única.

Dentre as condições citadas por Maldaner (1997), a primeira merece um destaque dentro do contexto deste trabalho, especialmente no que se refere a disposição do professor para um trabalho reflexivo. Para Nóvoa (1992) os cursos de formação devem não somente ser um lugar de aquisição de conhecimentos, mas também "um lugar de reflexão sobre as práticas". Schon (1992), ao considerar o professor como prático reflexivo, distingue três conceitos diferentes que integram o pensamento prático: conhecimento-na-ação, reflexão-naação e reflexão-sobre-a-ação. Tendo em vista a atividade prática aqui relatada, entendemos a reflexão como possibilitadora de tomada de consciência do próprio conhecimento, seja ele teórico e/ou prático, e a partir dessa tomada de consciência a possibilidade de aquisição e reorganização desse conhecimento.

Nessa perspectiva, é importante que o trabalho ligado à formação de professores em serviço seja conduzido por ações colaborativas e compartilhadas entre pesquisadores e professores, em uma perspectiva mais dialógica que leve em conta a realidade e as necessidades dos professores dando a eles oportunidade para escolher melhor seus caminhos, discutirem e refletirem sobre suas ações e com isso promover resultados mais efetivos tanto 
na pesquisa quanto na prática docente.

\section{Contexto e Metodologia}

Partindo da ideia de Lattari (2005, p. 2): “Olhar para o céu, simplesmente é apenas uma forma de ver um livro fechado. Olhar para o céu com questionamentos é a chave para abrir esse livro da natureza. O universo é um laboratório que deve ser explorado com a nossa inteligência”. Pensamos em uma proposta de atividade prática, que contemple a proposta teórica a qual defendemos durante o texto, na qual o professor seja mais participativo na própria formação, que possam visualizar a importância de modificar a metodologia adotada nas aulas de Astronomia, privilegiando a participação ativa nas aulas, dando espaço para atividades de observação sistemática do céu e com isso uma nova possibilidade de ensino para o tema abordado.

Este trabalho tem origem na investigação realizada por Alho (2019), a qual se constituía da realização e investigação de um curso de Astronomia de curta duração ofertado para professores de escolas rurais da região Sul de Minas Gerais. O curso, intitulado Astronomia na Prática foi ministrado pelo autor deste trabalho com colaboração dos coautores. Cabe destacar que especificamente para as atividades do curso, tanto o ministrante quanto os colaboradores são identificados no texto como instrutores.

Inscreveram-se para o curso 16 professores oriundos de três escolas rurais. Destes, 7 professores realizaram a atividade de construção do calendário Lunar. O curso teve caráter prático e foi estruturado em três encontros presenciais (EP) e três atividades virtuais (AV) que ocorreram entre os meses de fevereiro e maio de 2019 como mostra a Tabela 1.

Tabela 1 - Organização do curso.

\begin{tabular}{c|c|c|c}
\hline Encontros presenciais (EP) & $\begin{array}{c}\text { Carga } \\
\text { horária }\end{array}$ & Atividades Virtuais (AV) & $\begin{array}{c}\text { Carga } \\
\text { horária }\end{array}$ \\
\hline EP-1: $23 / 02 / 19$ & 4 horas & AV-1: 24/02 a 28/03/19 & 6 horas \\
\hline EP-2: $30 / 03 / 19$ & 4 horas & AV-2: 31/03 a 08/05/19 & 6 horas \\
\hline EP-3: $10 / 05 / 19$ & 4 horas & AV-3: 11/05 a 31/05/19 & 6 horas \\
\hline \multicolumn{2}{r|}{ Carga horária total dos EP: 12 horas } & \multicolumn{2}{c}{ Carga horária total dos EV: 18 horas } \\
\hline
\end{tabular}

Carga horária total do curso: 30 horas

Fonte: Autores.

Em cada encontro presencial foram expostos e discutidos com os professores os temas previamente escolhidos pelos mesmos por meio de apresentações orais. Após a apresentação e discussão dos aspectos teóricos de cada tema, foram realizadas atividades práticas/oficinas que versavam sobre os temas abordados. Nesse sentido, durante o curso os professores foram estimulados a construírem objetos de aprendizagem e recursos que 
pudessem auxiliar na explicação e no entendimento do fenômeno Astronômico estudado. Estão dispostos no Quadro 2 os temas que foram escolhidos pelos professores para cada EP, as atividades práticas/oficinas realizadas em cada encontro e as atividades virtuais $\mathrm{AV}$ propostas para serem realizadas por meio do ambiente virtual do curso.

Quadro 2 - Temas de Astronomia escolhidos pelos professores.

\begin{tabular}{|c|c|c|}
\hline Temas abordados & Atividades práticas & Atividades Virtuais \\
\hline EP-1 & \multirow{2}{*}{$\begin{array}{l}\text { Simulador das fases da } \\
\text { Lua } \\
\text { Construindo uma Luneta } \\
\text { com lente de óculos } \\
\text { Observação da Lua }\end{array}$} & $\mathrm{AV}-1$ \\
\hline $\begin{array}{l}\text { Fases da Lua, Instrumentos de } \\
\text { observação astronômicos }\end{array}$ & & $\begin{array}{l}\text { Construção de um } \\
\text { calendário lunar }\end{array}$ \\
\hline EP-2 & \multirow[b]{2}{*}{$\begin{array}{l}\text { Sistema Solar em escala } \\
\text { de tamanho reduzido }\end{array}$} & $\mathrm{AV}-2$ \\
\hline $\begin{array}{l}\text { Sistema Solar: Ordem, diâmetro } \\
\text { e distâncias entre os planetas }\end{array}$ & & $\begin{array}{l}\text { Construção do Sistema } \\
\text { Solar em escala de } \\
\text { distância a partir do Sol }\end{array}$ \\
\hline EP-3 & \multirow[b]{2}{*}{$\begin{array}{l}\text { Simulador do movimento } \\
\text { das estrelas e do Sol }\end{array}$} & AV -3 \\
\hline $\begin{array}{l}\text { Estrelas: Movimento das } \\
\text { estrelas no céu; Movimento do } \\
\text { Sol no céu e as estações do ano }\end{array}$ & & $\begin{array}{l}\text { Construção de um } \\
\text { Planisfério }\end{array}$ \\
\hline
\end{tabular}

Fonte: Autores.

Além de conteúdos e práticas, a proposta leva em conta as necessidades e opiniões dos professores em todo processo de elaboração do curso. Para isso, todas as etapas de desenvolvimento foram realizadas tendo como base as condições propostas por Maldaner (1997) na chamada parceria colaborativa citada anteriormente. Nesse sentido, todo o planejamento do curso foi feito com a participação efetiva dos professores participantes, o que inclui a escolha dos temas abordados, das atividades desenvolvidas, da carga horária, dos horários e do local realização.

A atividade relatada neste trabalho foi proposta como uma das atividades virtuais (AV) a serem desenvolvidas pelos professores durante o curso. Para a realização das AV os professores receberam orientações por meio da plataforma moodle ${ }^{4}$.

\footnotetext{
4 Moodle: Modular Object Oriented Distance Learning Environment. Trata-se de um sistema virtual de uso livre e colaborativo para o desenvolvimento e gerenciamento de cursos on-line ou ambientes virtuais de ensinoaprendizagem e de apoio a atividades presenciais. Site: $<\mathrm{https}: / / \operatorname{moodle} . o r g>$.
} 
No ambiente virtual os professores tiveram acesso a tutoriais, vídeos, artigos científicos, textos e hiperlinks. O prazo para a entrega das atividades no ambiente virtual encerrava-se sempre no dia anterior dos encontros presenciais conforme mostra a Tabela 1. Dessa forma, as atividades eram avaliadas para que os instrutores dessem o feedback aos participantes no encontro presencial seguinte.

O objetivo do feedback foi de discutir coletivamente com os professores noções, conceitos, dúvidas e curiosidades sobre o movimento lunar e suas fases. O Para Sadler (1989), o feedback tem por finalidade pedagógica fornecer informações relacionadas com a tarefa ou processo de aprendizagem, a fim de melhorar o desempenho numa tarefa específica e/ou o entendimento de um determinado assunto.

A descrição completa das atividades desenvolvidas no curso está discutida em Alho (2019), e aqui entendemos ser necessário apenas apontar que as outras atividades versavam sobre: Fases da Lua e instrumentos de observação astronômicos; Sistema Solar: ordem, diâmetro e distâncias entre os planetas; Estrelas: Movimento das estrelas no céu; Movimento do Sol no céu e as estações do ano; desenvolvimento de oficinas de construção de modelos sobre as fases da Lua e eclipses; Sistematização desses fenômenos com uso de softwares e recursos digitais. Associado ao conteúdo conceitual, mobilizaram-se diversas competências e habilidades, como: articulação e relação de múltiplos registros; raciocínio matemático de proporcionalidade e de espacialidade e visualização dinâmica do céu e da Lua e dos demais astros.

A observação e o registro das Fases da Lua foram planejados a partir dos seguintes objetivos de aprendizagem: i) construção e reconstrução de saberes sobre as fases da Lua pelos docentes, e ii) aprender o nosso satélite como um objeto astronômico passível de investigação e modelização científica. Para além dos objetivos de aprendizagem, as noções apresentadas a seguir também fizeram parte dos objetivos da atividade. São elas:

- Reconhecer que a Lua é observável em diferentes momentos, tanto durante o dia quanto à noite.

- Identificar como são as mudanças nas fases da Lua, durante os dias e semanas.

- Identificar e comparar os horários de saída e culminação da Lua e do Sol e suas relações.

- Reconhecer como a iluminação da Lua muda de dia para dia e sua relação com a posição do Sol.

A realização das observações permite que o professor se familiarize com a tarefa em questão. Seguir esse fenômeno ao longo de um dia e semanas e identificar seu movimento aparente significa imaginá-lo se movendo dentro de um espaço no céu. Desta forma pode abrir possibilidade para questionamentos sobre a localização do Sol, que determina a porção iluminada da Lua.

Além disso, ao comparar o caminho de ambos os astros no céu, é possível explorar alternativas e ver que, em geral, suas aparentes trajetórias não coincidem. Essa análise permite 
discutir com os participantes se os arcos das trajetórias da Lua e do Sol são as mesmas ou não, se a aparência da porção iluminada da Lua é a mesma nos dois hemisférios, e se a aparência visualizada depende da localização do observador na superfície terrestre.

A primeira atividade virtual (AV-1) intitulada construção de um calendário lunar foi pensada para que os professores relacionassem os conceitos apresentados e discutidos nos encontros presenciais. Para realizá-la, os professores deviam observar e fotografar o movimento da Lua ao longo de um mês e com as fotografias confeccionar um calendário lunar. $\mathrm{Na}$ página do curso os professores tinham acesso a um link com informações que auxiliaram na construção da atividade. As orientações para a realização da atividade disponíveis aos professores na plataforma moodle estão descritas no Quadro 3.

Quadro 3: Orientações para a elaboração e entrega da atividade virtual 1.

\section{ATIVIDADE VIRTUAL (AV-1)}

\section{Construindo um calendário Lunar}

Duracão: 24/02/19 a 28/03/19 (Formato: Individual ou em duplas)

Descricão: 1) fotografar a Lua uma vez por dia, caso consiga vê-la; 2) anotar data, hora e local da observação; 3) fazer o upload das fotos no moodle; 4) Faça aqui o "upload" das fotografias tiradas. É recomendado que cada foto tenha menos do que $1 \mathrm{Mb}$ pois o Moodle comporta no máximo $10 \mathrm{Mb}$ por tarefa. Importante: não é necessário fazer a foto no mesmo local nem no mesmo horário

Após fotografar a lua você deverá construir um calendário lunar com as fotografias. Você deve produzir um calendário semelhante ao que está disponível no link: $<$ http://astro.if.ufrgs.br/lua/lua.htm>. Você deve substituir as imagens da Lua que estão nesse calendário pelas fotos que você tirou.

Os dias que você não conseguir fotografar a Lua devem ficar sem nenhuma imagem. Depois de ter concluído o calendário, grave-o no formato PDF e faça o upload no moodle. Caso deseje fazer a atividade em dupla, inclua o nome de seu colega na caixa de texto. No decorrer da atividade anote suas percepções, dúvidas e curiosidades a respeito dos aspectos de visualização da Lua no céu. Elas serão discutidas no próximo encontro presencial.

Fonte: Elaborado pelo autor.

Não foram estabelecidos horários fixos para as observações pois nossa expectativa era a de que o decorrer da construção do calendário permitisse aos professores estabelecer relação com o objeto lunar, não apenas como 'algo' no céu, mas como um objeto a ser investigado e modelado, o qual apropriariam cientificamente, a ponto de elaborarem explicações sobre seus mecanismos e de realizarem previsões sobre suas futuras posições e fases.

Foi possibilitado que a atividade fosse feita em forma individual ou em duplas, pois alguns professores alegaram não ter aparelho de celular com câmera fotográfica de boa qualidade para fazer os registros. 
É importante destacar que a construção de representações a partir da posição de um observador terrestre é pouco comum nos livros didáticos brasileiros, já que seus autores, de maneira geral, preferem ilustrar o modelo das fases da Lua a partir da perspectiva em que o observador se encontra fora do plano da órbita terrestre (LAGO, 2013).

Como instrumento de coleta de dados, foram feitas análises dos calendários confeccionados e gravações em áudio dos discursos dos professores durante o feedback dos instrutores durante o segundo encontro presencial (EP-2). Durante o feedback, instrutores e professores estabeleceram um diálogo produtivo dentro de um espaço de trocas de informações, construções e reflexões coletivas acerca da atividade e aspectos do movimento lunar.

Cabe destacar que os professores que participaram do curso assinaram um termo de esclarecimento sobre os objetivos do estudo e de consentimento e autorização do uso das informações para fins de pesquisa e publicação cientifica. Além disso, a pesquisa foi aprovada pelo comitê de ética em pesquisa ${ }^{5}$.

\section{Apresentação e discussão dos dados}

Nessa atividade, os professores deveriam observar a Lua a olho nu, fotografá-la e construir um Calendário Lunar com as imagens. Solicitamos, como dito, o registro da Fase da Lua assim como o horário e o local de observação/registro. Assim, por meio do registro sistemático do fenômeno, os professores teriam, ao final, uma representação das posições e Fases da Lua num ciclo lunar a partir da perspectiva do observador terrestre.

Entre os professores que realizaram a atividade, seis decidiram fazê-la em duplas. Dessa forma, foram entregues quatro calendários elaborados pelos professores aqui identificados como P1, P2, P3, P4, P5 e P6. Desses, apenas o professor P1 fez a atividade de forma individual. Como a maioria dos registros é semelhante, optamos por apresentar apenas dois dos quatro calendários confeccionados pelos professores.

A tarefa de registro revelou-se trabalhosa e, ao longo do processo, os professores relataram dificuldades que os impediram de elaborar um registro adequado, como por exemplo: nuvens impediam a observação correta da fase e posição, dias e noites com chuvas, além de problemas de agenda de trabalho que impediram a realização dos registros.

As dificuldades que surgiram no decorrer da atividade acabaram gerando um tipo de registro que acabou aprimorando o uso dos calendários para previsão das fases, relação desconhecida pela maioria dos professores participantes. Além disso, os calendários confeccionados pelos professores nos deram suporte durante o feedback, permitindo discutir junto com os professores as lacunas deixadas durante a atividade, o processo de representação da lunação bem como a posição relativa considerando a observação geocêntrica do sistema Sol-Terra-Lua.

\footnotetext{
${ }^{5}$ Número do parecer do comitê de ética em pesquisa: 3.080 .314
} 
Como instrumento de verificação e correção dos registros produzidos pelos professores, utilizamos o simulador de observação astronômica Stellarium ${ }^{6}$. Com o simulador é possível rever o fenômeno a partir do local e horários de registro de cada calendário. Nesse sentido foi possível verificar se as imagens presentes correspondiam fielmente à fase, posição e local da Lua em todos os calendários produzidos.

Todos os registros estavam incompletos, porém expressavam posições e fases simultâneas e com aspectos visuais corretos. Os registros produzidos pelos professores P1, P2 e P3 exemplificam os aspectos ditos anteriormente como mostram as Fig. 9 e 10.

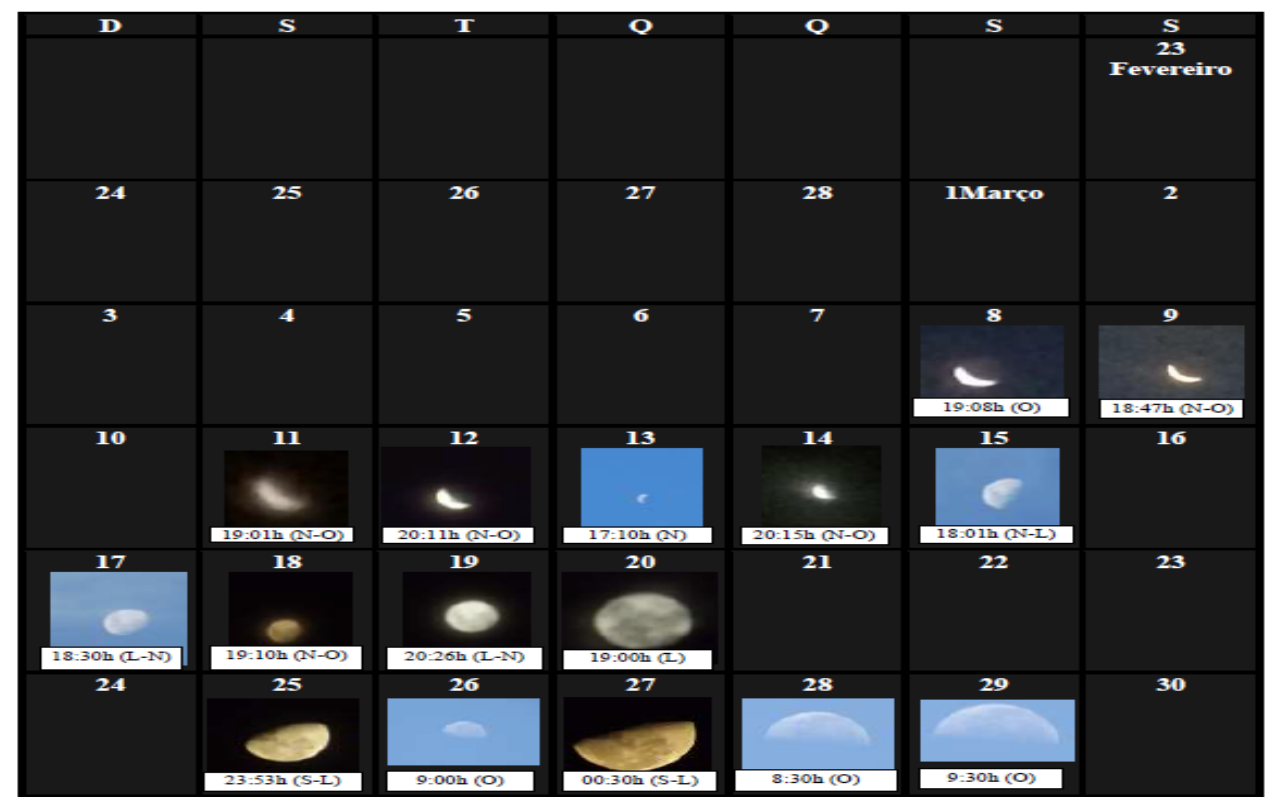

Fig. 9 - Calendário lunar confeccionado pelo professor P1. Fonte: Autores.

Os registros permitem visualizar a sucessão das fases e perceber uma historicidade cíclica. O professor P1 registrou os horários e a localização cardeal de observação do evento. Isso permitiu que puséssemos em discursão os locais de Nascimento (entrada) e de Ocaso (saída) da Lua para um observador na superfície terrestre. O diálogo a seguir entre o instrutor e o professor P1 mostra um trecho dessa discussão.

Instrutor: Vocês conseguem ou conseguiram notar algo inusitado no calendário? Algum comportamento que causou estranheza ou questionamento?

P1: Percebi que ela sempre nasce entre o Leste e Norte e se põe entre o Norte e o Oeste. Certo? Mas durante alguns dias ela nascia em uma direção, depois ela mudou o local onde nascia. Notei a mesma coisa quando ela ia se por. Isso acontece mesmo?

\footnotetext{
${ }^{6}$ Stellarium: O programa de computador Stellarium, de acordo com a página de internet oficial, é um planetário de código aberto para o seu computador. Ele mostra um céu realista em três dimensões igual ao que se vê a olho nu, com binóculos ou telescópio.
} 
Instrutor: Sim, isso acontece. Assim como o Sol, a Lua possui um movimento aparente, ou seja, aquele que observamos aqui da Terra. Isso acontece devido à diferença entre o período sideral da Terra e da Lua. A Terra leva cerca de 365 dias para dar uma volta completa ao redor do Sol. Já a Lua leva 27 dias para dar uma volta completa ao redor da Terra. Essa diferença faz com que a Lua mude quase que diariamente os locais de entrada e saida no horizonte.

Tanto neste como nos demais relatos fica claro que durante a construção da atividade prática os professores foram capazes de refletir durante a ação e sobre a mesma, ou seja, a atitude de pensar sobre o que foi feito ao mesmo tempo em que realizaram a atividade. Para Perez Gómez (1992), a reflexão na ação é o melhor instrumento de aprendizagem, pois "no contato com a situação prática não só se adquirem novos saberes, esquemas e conceitos como se aprende o próprio processo dialético da aprendizagem".

Em ambos os registros é possível observar que entre os dias 8 e 17 de março a Lua apresentava um aumento diário de sua face iluminada, caracterizando sua fase crescente. Este aspecto mostra que nem sempre o número de dias entre fases consecutivas é de 7 dias (um quarto de 29,5 dias - período de lunação) como a maioria das pessoas interpretam.

P2: Depois de uns quatro dias observando a Lua, percebi que ela foi crescendo durante aquele intervalo [referindo-se aos dias 11 a 15 de março] e depois ela ficou totalmente iluminada. Nesse caso, é certo dizer que sempre a fase crescente vem antes da fase cheia?

Instrutor: Exatamente. Existe um ciclo de fases que sempre ocorre de forma consecutiva.

P3: Então, durante o mês eu consigo ver todas as fases da Lua?

P1: Acho que dá P3. No calendário dá pra notar que nesses dias aqui [referindo-se aos dias 08 ao dia 17, Fig. 9] que ela tá na fase crescente. Se ela estava crescente nesses dias isso significa, eu acredito né, que antes ela estava na fase nova. Ai, nos dias 18, 19, 20 até o dia 24 ela vai pra fase cheia [referindo-se a Fig. 10]. Aí, se a gente olhar, aqui ela começa a entrar na minguante [referindo-se ao dia 31 da Fig. 10] e depois ela passa pra nova [fase Nova] de novo.

Instrutor: Sim. Foi como apresentamos no último encontro. À medida que a Lua viaja ao redor da Terra ao longo do mês, ela passa por um ciclo de fases, durante o qual sua forma parece variar gradualmente. O ciclo completo dura aproximadamente 29,5 dias chamado de lunação.

Nos trechos apresentados acima, é possível notar que a discussão sobre os calendários permitiu aos professores verificar a sucessão das Fases da Lua além de promover momentos de compartilhamento de dúvidas e aprendizagens, propiciando o estabelecimento 
de relações entre a atividade de observação e construção do calendário e de aspectos sobre o fenômeno estudado.

Sabendo que a fase Nova antecede a fase Quarto-Crescente, também foi possível interpretar junto com os professores que a Lua provavelmente esteve em sua fase Nova entre os dias 2 e 7 de março, o que justifica a ausência de registros nesses dias em todos os calendários.

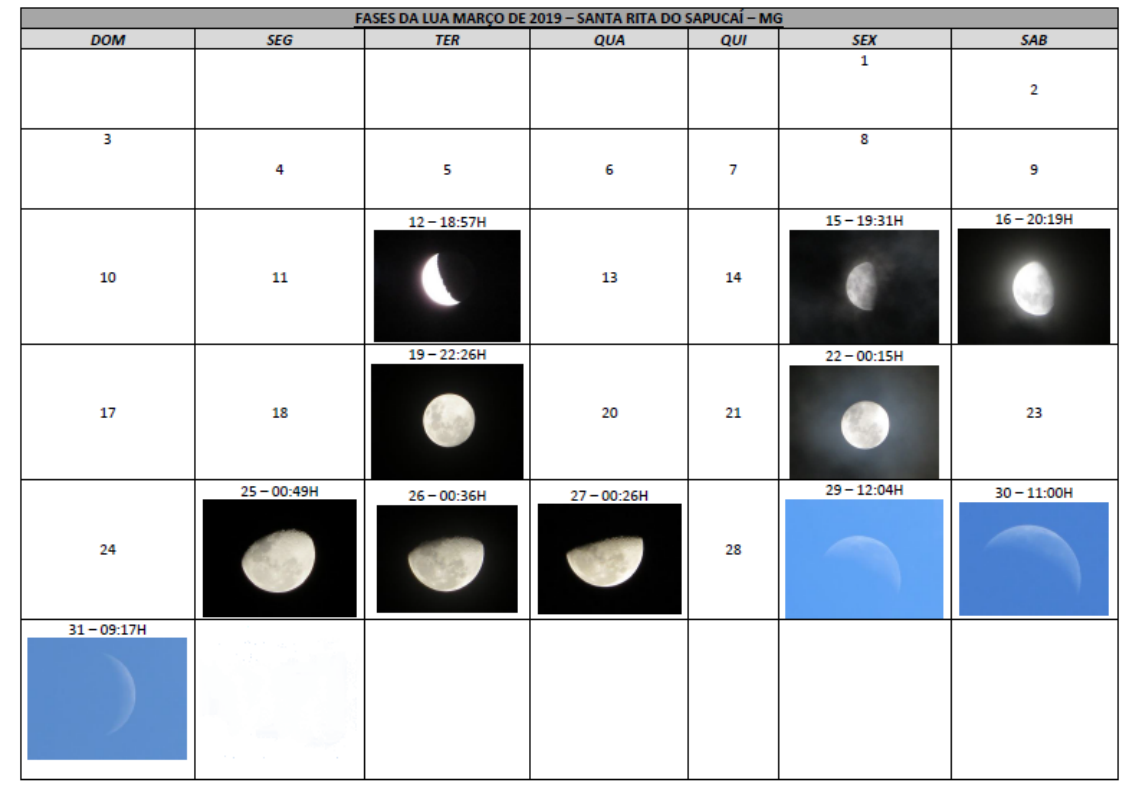

Fig. 10 - Calendário lunar confeccionado pelos professores P2 e P3. Fonte: Autores.

Outro aspecto discutido entre os professores durante o feedback foram os registros produzidos entre os dias 25 e 30 de março. Nesse período, em ambos os calendários é possível identificar que a Lua estava em sua fase minguante. Entretanto, como cada professor fez seu registro em horários diferentes, a visualização da porção iluminada do satélite apresenta formatos diferentes conforme apresenta os recortes (a) e (b) da Fig. 11.

É possível notar que nos dias 25 e 27 a porção iluminada da Lua em ambos os registros apresenta o formato de "U", com a parte inferior iluminada. Contudo, no dia 26 o formato da Lua no registro do professor P1 Fig. 11(a) tem forma de " $\cap$ ", com a parte superior da Lua iluminada. Já o registro feito pelos professores P2 e P3 Fig. 11(b) apresenta a forma de "U” com a parte inferior iluminada.

A diferença entre as imagens foi apresentada pelos tutores e discutida entre os professores durante o feedback. A respeito desse momento, são apresentados a seguir alguns excertos referentes ao diálogo entre o instrutor e os professores. 

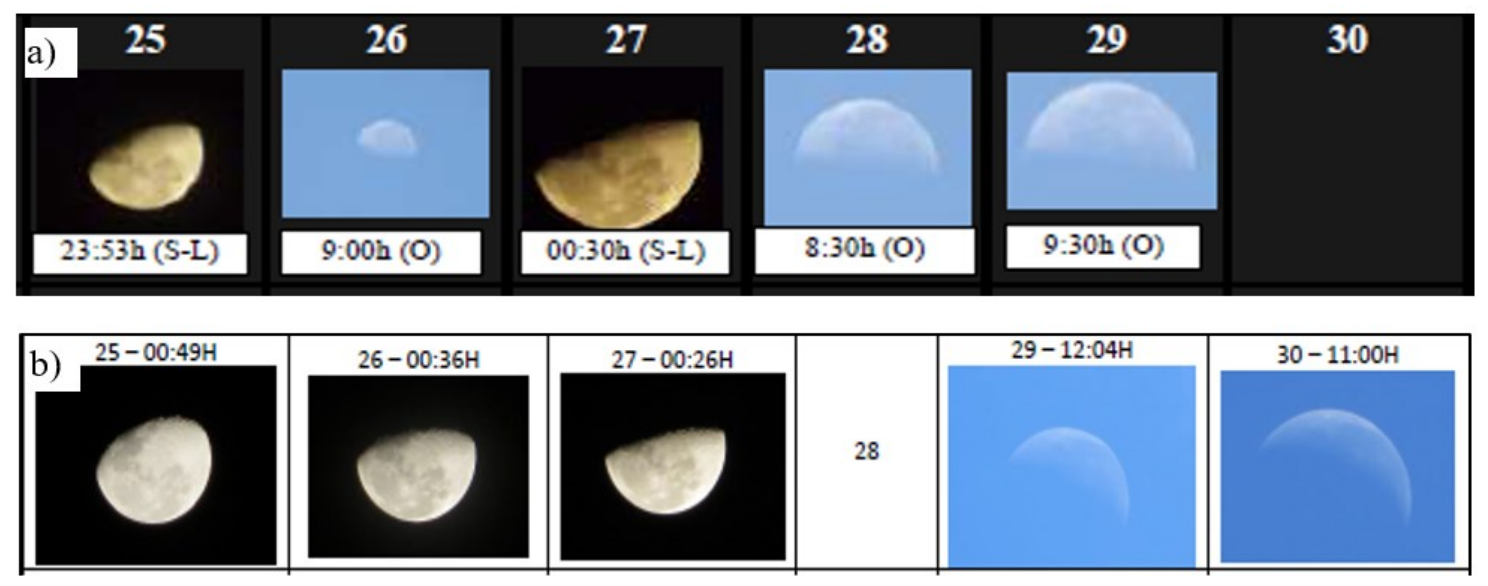

Fig. 11 - (a) Recorte do registro de P1 entre os dias 25 e 30 de março de 2019. (b) Recorte do registro de P2 e P3 no mesmo periodo. Fonte: Autores.

Instrutor: Observando os últimos cinco dias no calendário que P1 fez. Tem dois dias que a parte de baixo está iluminada e tem três dias que a parte de cima está iluminada. Por que existe essa diferença? A face iluminada da Lua é a mesma, mas as imagens são muito diferentes! Por que isso?

P6: Porque as duas primeiras fotos foram tiradas durante o dia e as três últimas foram tiradas durante a noite.

P1: Então, a noite ela estava aqui né, mais ou menos próxima ao hospital [apontando para o lado que a Lua nasce]. Ai quando foi cedo ela estava nessa outra posição aqui [apontando para o lado em que a Lua se põe]. As fotos que eu tirei durante o dia foram as nove, nove e meia da manhã, já as da noite eu tirei umas onze e meia, quase meia noite.

Os excertos mostram que a discussão coletiva sobre os formatos diferentes que cada calendário apresentava em virtude dos diferentes horários e locais nos quais foram feitos os registros permitiram aos professores observar não apenas as mudanças na porção iluminada da Lua no decorrer do seu ciclo mas também que o formato da face lunar iluminada nem sempre apresenta os formatos das letras " $C$ " e " $D$ ", podendo apresentar também as formas de "U" e " $\cap "$ dependendo da posição do observador na Terra como mostra os excertos dos professores P4 e P6.

P4: Então, dependendo do horário que eu observo, a Lua pode estar de um jeito ou de outro?

P6: Eu acho que dependendo da posição do observador na Terra, o formato da parte iluminada da Lua muda. Foi o que vimos no encontro passado. A situação que discutimos sobre o formato de " $C$ " e de " $D$ " que nem sempre acontece e que a gente vê muito nos livros. 
A partir do aspecto discutido entre os professores, o instrutor fez o seguinte questionamento:

Instrutor: Uma pessoa que está no hemisfério norte vê a Lua com os mesmos formatos que nós aqui do hemisfério Sul?

P6: Eu acredito que deve ser diferente. Porque até aqui mesmo a gente percebe que nem sempre a Lua tem formato de "Letra C" quando está crescente e de "Letra D" quando está minguante! Eu percebi isso nas fotos que tirei.

Os trechos mostram que os professores conseguiram através da realização da atividade e da discussão coletiva compreender os fenômenos de forma não literal e não arbitrária. Os diferentes formatos que a Lua apresenta no céu foram explicados anteriormente na seção "Considerações científicas sobre as fases da Lua".

Muitos professores acreditam que devido a Terra estar girando em torno de seu eixo, posicionada entre o Sol e a Lua, ao girar, vê-se o Sol durante o dia e a Lua à noite (CAMINO, 1995). Assim como apontado por Camino (1995), o fato de a Lua poder ser vista durante o dia ainda é um evento desconhecido por muitos, como mostram os excertos de P2 e P5.

P2: No meu caso, tinha dia que quando eu acordava cedo pra trabalhar dava de ver a Lua belezinha, mas tinha dia que não dava de ver nada. Tinha dia que dava pra ver durante o dia em outros só a noite era visível. Nunca parei pra pensar que a Lua aparecia durante o dia também.

P5: Olha, eu realmente nunca tinha parado para observar a Lua. Essa atividade me fez pensar, que coisa interessante não é mesmo! A Lua está quase todos os dias no céu, inclusive durante o dia. É muito legal (...)

A autonomia dada aos professores para a realização da atividade foi importante, pois foi possível observar que todos os calendários possuem registros da Lua também durante o dia.

Nos excertos registrados é possível identificar o momento da tomada de consciência dos professores de que a Lua também pode estar no céu durante o dia. No relato de P2 nota-se que ao realizar seus registros o professor tomou consciência que o satélite também pode ser visualizado no céu durante o dia. Destacamos que não foram feitas discussões mais aprofundadas sobre esse aspecto. Os excertos apresentados tratando-se de uma constatação apontada anteriormente por Camino (1995) e que julgamos ser pertinente a apresentação.

Os registros produzidos permitiram fazer referência à face oculta da Lua. Esse aspecto peculiar de nosso satélite foi levantado por um dos professores durante o feedback. A resposta do instrutor se ateve aos aspectos apresentados anteriormente na seção Considerações científicas sobre as fases da Lua. Por isso, mostraremos apenas o questionamento feito pelo professor.

P1: (...) então, eu pensava que isso era apenas uma coisa de filme de ficção 
cientifica (risos). Tem como saber se a Lua tá sempre com a mesma face voltada pra Terra? Isso acontece realmente?

É possível verificar esse aspecto fazendo uma análise das melhores imagens produzidas pelos professores. Selecionamos as imagens cuja a qualidade possibilitaram visualizar e comparar o relevo da superfície da Lua vista da Terra. A partir da análise e comparação das imagens é possível inferir que a Lua mantém sempre um de seus hemisférios voltado para a Terra.

A Fig. 12 faz uma comparação entre (a) a fotografia da Lua em sua fase cheia feita por P2 e P3 no dia 19 de março de 2019 às 22:26 h e uma imagem retirada do programa Stellarium no mesmo local e horário e b) fotografia da Lua em sua fase cheia tirada no dia 22 de março de 2019 às 00:15 h com uma imagem retirada do programa Stellarium no mesmo local e horário. Os registros dos professores P2 e P3 foram feitos no município de Santa Rita do Sapucaí, Brasil (-22.250205, -45.704784). Dessa forma, ajustamos as coordenas geográficas do Stellarium para o mesmo local.

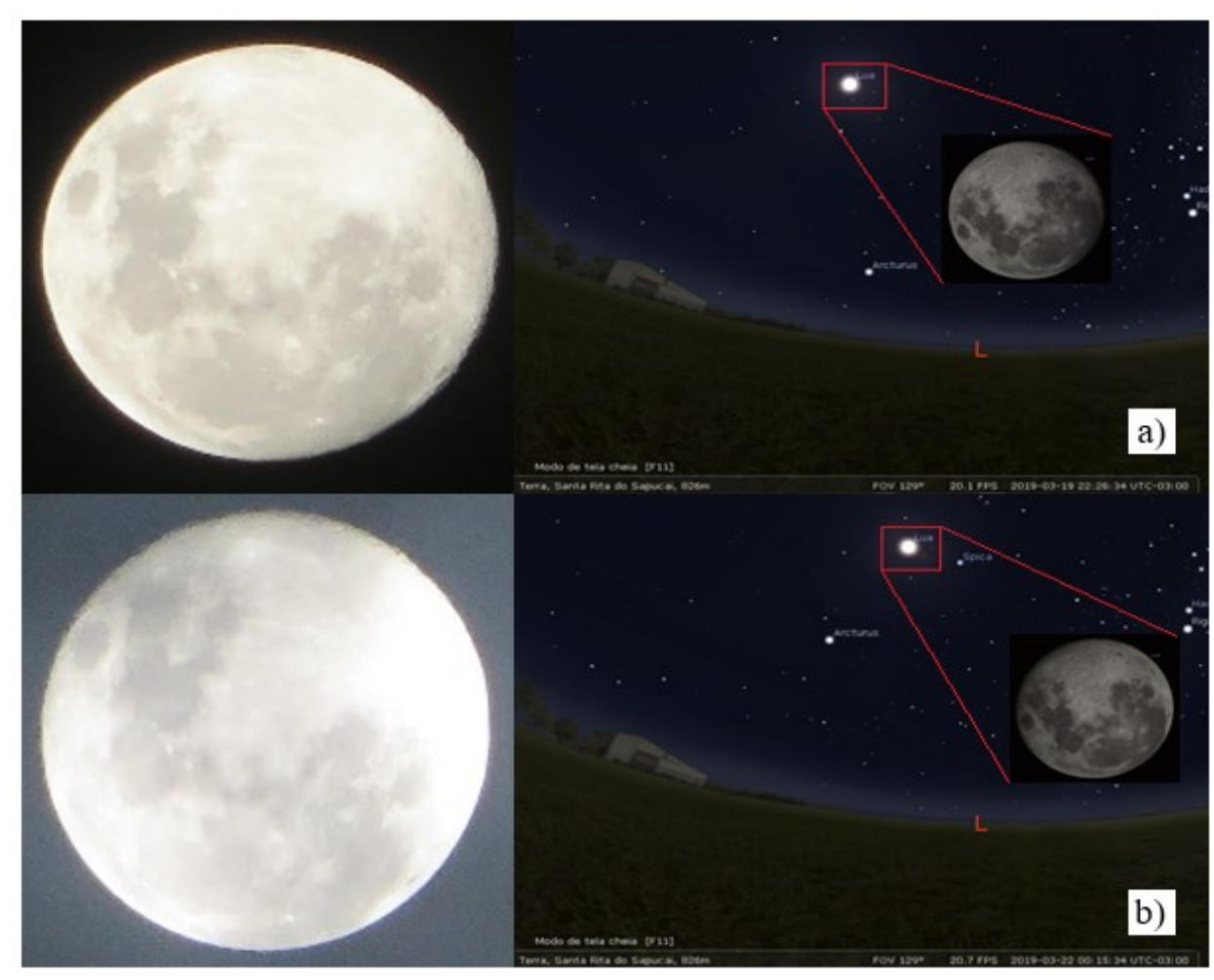

Fig. 12 - Comparação entre as fotografias da Lua tiradas pelos professores P2 e P3 com imagens geradas pelo programa Stellarium. 12(a) (à esquerda) imagem tirada em 19/03/19 às 22:26 hem Santa Rita do Sapucaí; (à direita) imagem gerada pelo Stellarium no mesmo local e horário. 12(b) (à esquerda) imagem tirada em 22/03/19 às 00:15 h em Santa Rita do Sapucaí; (à direita) imagem do Stellarium no mesmo local e horário. Fonte: Autores. 
As Fig. 12(a) e 12(b) ilustram claramente que a Lua apresenta sempre o mesmo relevo voltado para a Terra em dias e horários diferentes. É possível ver que as crateras que aparecem nas fotografias tiradas pelos professores são as mesmas das imagens geradas pelo Stellarium. A comparação entre as imagens retiradas do Stellarium com as fotografias feitas pelos professores traz credibilidade aos registros feitos pelos docentes e ratificam a discussão realizada sobre este fenômeno na seção anterior.

A partir dos registros produzidos também foi possível discutir sobre as posições da Lua e do Sol no momento em que as fotografias foram feitas pelos professores. Para este estudo, foi levantada a seguinte questão: Em que direção a Lua recebia iluminação no momento em que foi fotografada?

Outro aspecto que orientou a discussão foi analisar o plano de fundo de cada imagem, ou seja, a cor que o céu apresentava durante cada registro. Esse último aspecto foi importante para determinar a presença ou ausência do Sol no céu e em qual das fases Lua e Sol podem ser vistos juntos. Essas informações deram aos professores orientações para identificar a posição do Sol no céu nos diferentes dias, horários e fases. Com as imagens dos calendários foi possível discutir com os professores os seguintes aspectos sobre as posições relativas da Lua e do Sol:

Na fase Cheia, Lua e Sol, vistos da Terra, estão em direções opostas. Nessa fase a Lua está no céu durante toda a noite, nasce quando o Sol se põe e se põe no nascer do Sol. A Fig. 13 mostra a simulação feita pelo Stellarium das posições da Lua Cheia e do Sol no dia 19 de março de 2019 às 22:26 h. A linha verde solida representa horizonte passando pelos pontos cardeais. Nota-se que a Lua aparece acima da linha do horizonte e Sol está abaixo. A imagem no canto superior esquerdo é a fotografia feita pelos professores P2 e P3 neste dia.

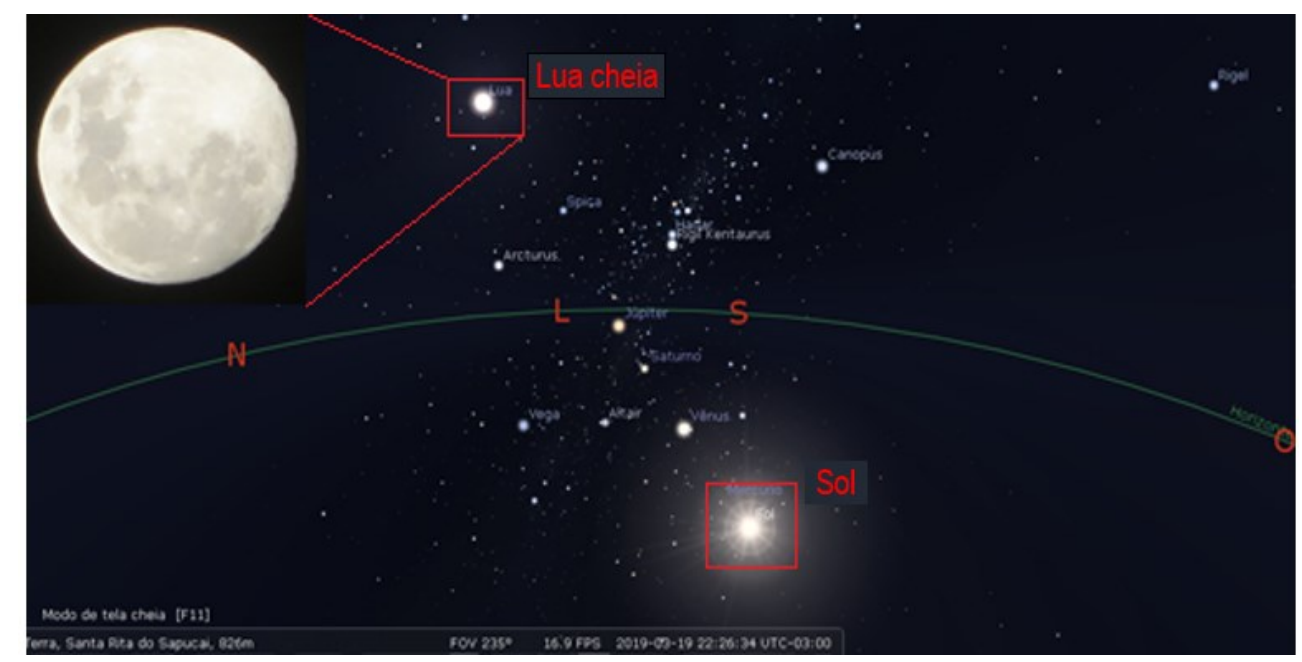

Fig. 13 - Imagem gerada pelo Stellarium da Lua Cheia e do Sol em direções opostas. A imagem apresentada no canto superior esquerdo é a fotografia feita por P2 e P3 em 19/03/19 às 22:26 h. Fonte: Autores. 
Na fase Nova, Lua e Sol, vistos da Terra, estão na mesma direção. Nessa fase, a Lua está no céu durante o dia, nascendo e se pondo aproximadamente junto com o Sol. A Fig. 14 apresenta a simulação feita pelo Stellarium das posições da Lua e do Sol em sua fase Nova no dia 05 de março de 2019.

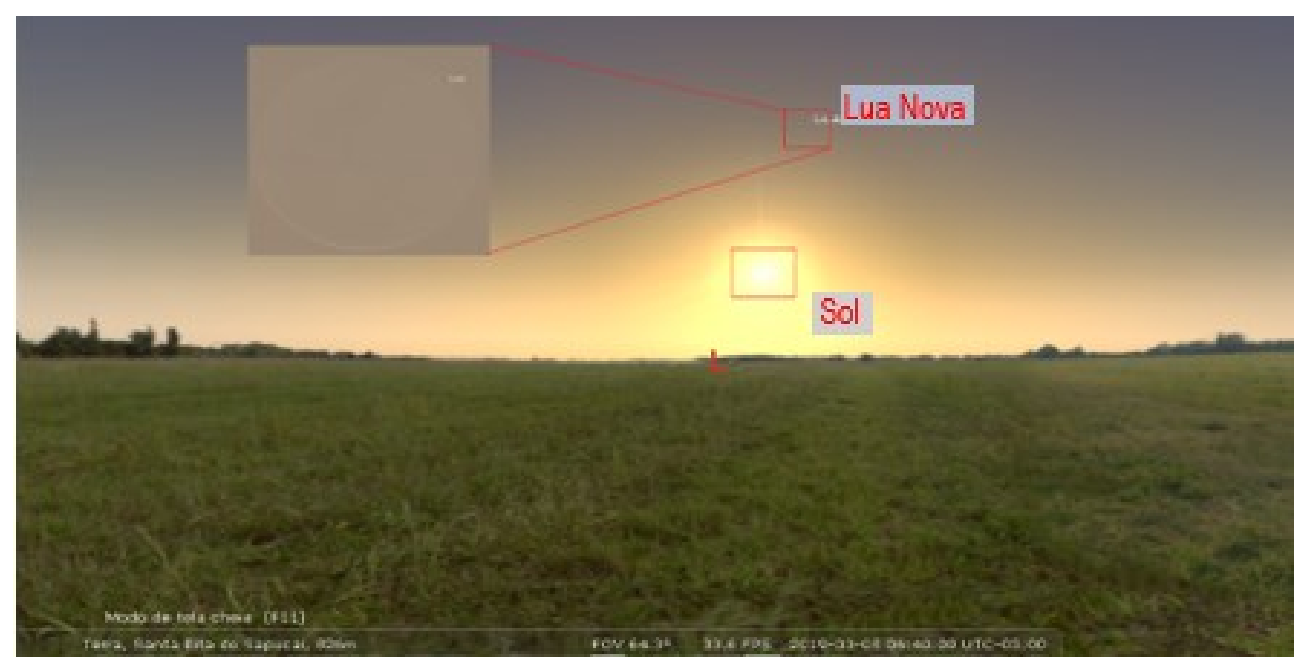

Fig. 14 - Imagem gerada pelo Stellarium da Lua Nova e do Sol praticamente na mesma direção no dia 05/03/19 às 06:40 h. A imagem apresentada no canto superior esquerdo é uma ampliação da face da Lua. É possível notar que Lua e Sol nascem no Leste praticamente juntos. Fonte: Autores.

Na fase Quarto-Crescente, a Lua está sempre a Leste do Sol e, portanto, sua parte iluminada está sempre voltada para o Oeste. Nessa fase Lua e Sol podem ser vistos juntos no céu pela tarde, a Lua nasce aproximadamente ao meio-dia e se põe aproximadamente a meianoite. A Fig. 15 apresenta a simulação feita pelo Stellarium da Lua em sua fase QuartoCrescente no dia 13 de março de 2019 às 17:10 h. À direita a ampliação da face da Lua mostra que a parte iluminada está voltada para o Oeste.

Em sua fase Quarto-Minguante, a Lua está a Oeste do Sol, que ilumina seu lado voltado para o Leste. Nessa fase, Lua e Sol podem ser vistos juntos no céu pela manhã, a Lua nasce aproximadamente à meia-noite e se põe aproximadamente ao meio-dia. A Fig. 16 apresenta a simulação feita pelo Stellarium no dia 31 de março de 2019 às 09:17 h. A imagem no canto superior esquerdo é a fotografia feita pelos professores P2 e P3 No mesmo dia e horário. A ampliação mostra que a porção iluminada da Lua está voltada para o Leste.

A maioria dos professores soube associar corretamente o lado iluminado da Lua com o lado voltado para o Sol. Contudo, demostraram ter dificuldade em desenvolver uma visão espacial correta das posições da Lua e do Sol nas diferentes fases.

De um modo geral, a atividade alcançou um resultado satisfatório. A abordagem realizada fez com que os professores prestassem mais atenção nos acontecimentos em seus cotidianos, isto gerou discussões produtivas no decorrer do curso. Além disso, ao serem 


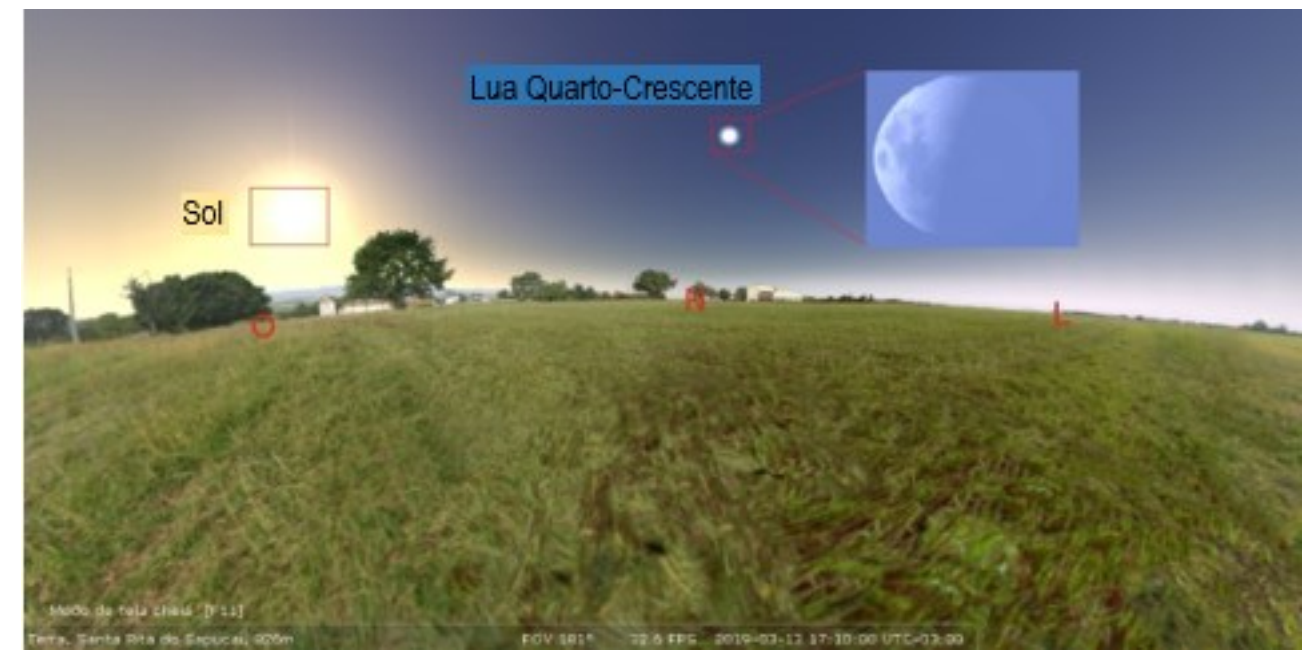

Fig. 15 - Imagem gerada pelo Stellarium da Lua em sua fase Quarto-Crescente e do Sol juntos no céu no dia 13/03/19 às 17:10 h. A imagem apresentada à direita é uma ampliação da face da Lua com sua parte iluminada voltada para o Oeste. Fonte: Autores.

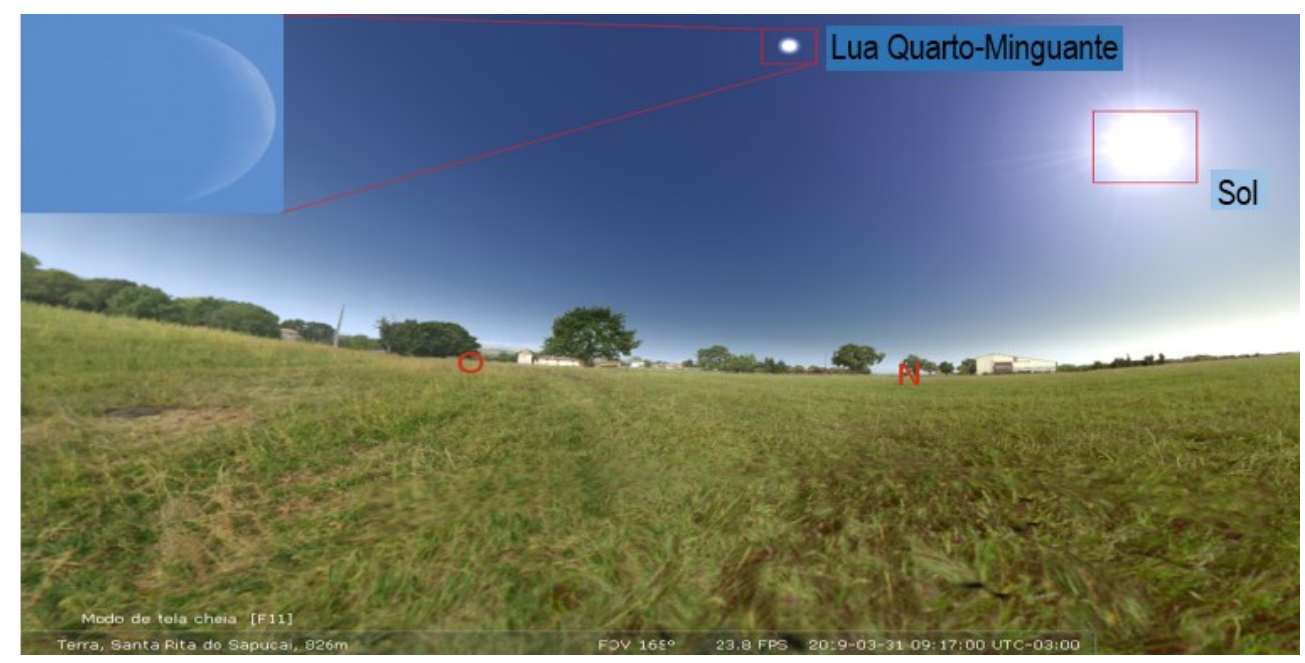

Fig. 16 - Imagem gerada pelo Stellarium da Lua em sua fase Quarto-Minguante e do Sol juntos no céu no dia 31/03/19 às 09:17 h. A imagem apresentada à direita é uma ampliação da fotografia feita pelos professores P2 e P3 no mesmo dia e horário. Fonte: Autores.

perguntados sobre a viabilidade da atividade ser reproduzida com os alunos, todos os professores foram unanimes ao dizer que pretendiam reproduzir a atividade em suas escolas.

Deste modo, com a atividade de observação, registro e construção de um calendário lunar foi possível compreender o movimento aparente da Lua no céu. Ademais, com os registros os docentes conseguiram: perceber que a Lua pode ser observada em diferentes momentos no céu; identificar as mudanças nas fases da Lua; identificar e comparar os horários de entrada e saída da Lua no céu em comparação com o Sol; e ainda entender o porquê da Lua sempre estar com a mesma face voltada para a Terra. 
Em outras palavras, a vivência da atividade de observação e registro das fases da Lua se traduziu em um autêntico aprendizado do modelo científico de lunação, que permitiu aos professores refletir, prever, compreender e explicar o fenômeno além de apropriarem-se de um "novo" recurso metodológico para o ensino do tema.

É importante dizer que não tivemos a intenção de montarmos um manual ou um "receituário" e que as possibilidades não findam com este texto: o objeto pode ser amplificado, variado e certamente pode ser abrangente em temas e conteúdos a serem investigados e discutidos. Além disso, a atividade pode ser incrementada com uso de outras ferramentas como, por exemplo, a inclusão de aplicativos móveis e softwares de reconhecimento de céu que permitem acompanhar diferentes astros em tempo real.

A atividade de construção de um calendário lunar como recurso pedagógico na formação continuada de professores, discutida aqui, apresenta-se como uma ferramenta de apoio para a introdução dos conceitos sobre as fases e movimento da Lua. Além disso, pode fornecer ao professor um novo recurso de ensino para o estudo desse fenômeno.

\section{Conclusão}

A proposta de construção de um calendário lunar como ferramenta para o entendimento das fases da Lua dentro de um curso de formação continuada de professores da educação mostrou-se eficiente e aberto para a implementação e discussão de outros fenômenos relacionados ao sistema Sol-Terra-Lua, como por exemplo a ocorrência das marés e de eclipses.

Para experiências futuras, no entanto, é importante destacar que o cronograma da atividade necessitou de alterações, por conta do clima. Além disso, para a realização da atividade, é importante que os participantes tenham celulares com câmera fotográfica de boa qualidade, o que irá produzir registros mais nítidos e ricos em detalhes.

É possível inferir que a atividade prática aliada à discussão coletiva sobre o fenômeno produziu resultados favoráveis à construção do conhecimento cientifico sobre as Fases da Lua. Os professores conseguiram, a partir da confecção do calendário e das discussões em grupo, estabelecer relações entre os formatos da porção iluminada da Lua, seus horários de saída e entrada com o ciclo de fases. No entanto, em alguns momentos demostraram ter dificuldade em desenvolver uma visão espacial correta das posições da Lua e do Sol nas diferentes fases, o que pode ser superado com o uso de simulações sobre o fenômeno.

Os resultados apresentados aliados à análise estabelecida permitem estabelecer as seguintes premissas: A primeira é a de que a elaboração de um curso de formação organizado e conduzido de forma colaborativa pode proporcionar melhores condições de investigação e de formação docente, na medida em que possibilita ao professor participar de seu processo formativo, compartilhando ideias, dúvidas e aprendizagens. A segunda é que ao propor uma ação formativa centrada nos professores, as relações entre pesquisa e educação básica possam 
ser estreitadas, posto que a primeira busca a última não apenas para o desenvolvimento de projetos, mas também na tentativa de contribuir para a melhoria das práticas educativas.

Analisando a maneira como os professores elaboraram, participaram e compartilharam os conceitos sobre as fases da Lua e seus movimentos durante as atividades do curso, entendemos que uma proposta de atividade prática que agrega em diferentes vertentes a construção coletiva de conhecimentos, a observação sistemática, o registro e construção de um recurso que facilite o entendimento de um fenômeno (neste caso do ciclo lunar), é relevante tanto para a aquisição de conhecimentos científicos sobre o fenômeno quanto como proposta para a elaboração de ações de formação continuada menos centralizadas e mais compatíveis com a realidade do professor.

Os relatos dos cursistas mostram que a atividade de observação e de registro das fases lunares, aliada à discussão coletiva, apresentou-se como um método válido e eficiente tanto para a aquisição de conhecimentos quanto para o exercício de reflexão sobre a ação durante o processo de aprendizagem. Além disso, a utilização de atividades práticas como norteadoras do processo formativo, quando emanadas das necessidades dos professores, contribuem para encaminhar discussões a respeito de estratégias didáticas que podem auxiliar o professor na sua prática pedagógica.

Finalizamos com o entendimento de que a elaboração de cursos de formação continuada em Astronomia cujo público alvo é constituído de professores da educação básica deva ser discutida e planejada em uma parceria colaborativa entre professores da educação básica, professores universitários, alunos de graduação e pós-graduação e escolas. Somente dessa forma será possível oferecer um processo formativo adequado à realidade e às necessidades dos docentes. Além disso, é importante que os temas de Astronomia abordados nos cursos de formação quando possível sejam vivenciados na prática, de forma a dar sentido e significado ao fenômeno estudado.

\section{Referências}

ALHO, K. R. Astronomia na prática: a prática como eixo central no processo de formação continuada de professores. 2019. 143 f. Dissertação (Mestrado em Educação em Ciências) - Instituto de Física e Química, UNIFEI, Itajubá.

ANDRADE, M. L. F.; MASSABNI, V. G. O desenvolvimento de atividades práticas na escola: um desafio para os professores de Ciências. Ciência \& Educação, Bauru, v. 17, n. 4, p. 835-854, 2011.

BRASIL. Secretaria de Educação Média e Tecnologia. Parâmetros Curriculares Nacionais: terceiro e quarto ciclos do ensino fundamental - ciências naturais. Brasília. MEC/SEMTEC. 1998. 
BRASIL, Ministério da Educação. Base Nacional Comum Curricular. Disponível em: $<$ http://basenacionalcomum.mec.gov.br/\#/site/inicio>. Acesso em: 02 abr. 2021.

BRETONES, P. S. A Astronomia na formação continuada de professores e o papel da racionalidade prática para o tema da observação do céu. 2006. $281 \mathrm{f}$. Tese (Doutorado em Ciências) - Instituto de Geociências, USP, Campinas.

CAMINO, N. Ideas previas y cambio conceptual en astronomía. Un estudio con maestros de primaria sobre el día y la noche, las estaciones y las fases de la luna. Enseñanza de las ciencias: Revista de investigación y experiencias didácticas, Patagonia, v. 13, n. 1, 1995, p. $81-96$

CANALLE, J. B. G. Explicando astronomia básica com uma bola de isopor. Caderno Brasileiro de Ensino de Física, v. 16, n. 3, 1999, p. 317-334.

COSTA, J. R. V. Um hipermídia sobre fases da lua para o ensino de astronomia a distância. 2011. 95 f. Dissertação (Mestrado em Ensino de Ciências Naturais e Matemática) Universidade Federal do Rio Grande do Norte, UFRGN, Natal.

DOTTORI, H. A. Ensinando ciências através da Astronomia: recursos didáticos e capacitação de professores. 2003. Disponível em: <http://www.if.ufrgs.br>. Acesso em: 14 abr. 2018

GALIAZZI, M. C. et al. Objetivos das atividades experimentais no ensino médio: a pesquisa coletiva como modo de formação de professores de Ciências. Ciência \& Educação, v. 7, n. 2, p. 249-263, 2001.

GHEZZI, I.; RUGGLES, C. C. A 2300-year-old solar observatory in coastal Peru. Science, v. 315, n. 5816, p. 1239-1243, 2007.

GONZATTI, S. E. M et al. Ensino de astronomia: cenários da prática docente no ensino fundamental. Revista Latino-Americana de Educação em Astronomia, n. 16, p. 27-43, jul. 2013.

GOUVEIA, M. S. F. Cursos de Ciências para professores do $1^{\circ}$ grau: elementos para uma política de formação continuada. 1992. 274f. Tese (Doutorado em Educação) - Faculdade de Educação, UNICAMP, Campinas. 
LANGHI, R. Aprendendo a ler o céu: pequeno guia prático para a astronomia observacional. Campo Grande, Editora UFMS, 2011.

LANGHI, R.; NARDI, R. Formação de professores e seus saberes disciplinares em Astronomia Essencial nos anos iniciais do Ensino Fundamental. Revista Ensaio Pesquisa em Educação em Ciências, Belo Horizonte, v. 12, n. 2, p. 205-224, 2010.

LANGHI, R.; NARDI, R. O que dizem os pesquisadores brasileiros sobre as justificativas para o ensino de astronomia. In: ENCONTRO DE PESQUISA EM ENSINO DE FÍSICA, 13, 2011, Foz do Iguaçu. Atas... Paraná: SBF, 2011. 1 CD.

LATTARI, C. J. B. et. al. Construindo o conhecimento do universo a partir do indivíduo: ensino de astronomia no ensino fundamental. In: SIMPÓSIO NACIONAL DE ENSINO DE FÍSICA, XVI, Rio de Janeiro. Atas... Rio de Janeiro: CEFET-RJ, 2005. (CD-ROM, arquivo: p73-90.pdf)

KANTOR, C. A. A ciência do céu: uma proposta para o ensino médio. 2001. Dissertação (Mestrado em Educação) - Instituto de Física, Departamento de Física Experimental, USP, São Paulo.

MALDANER, O. A. A formação inicial e continuada de professores de química: professores/pesquisadores. Ijuí: Editora UNIJUÍ, 2000. 424 p.

MALDANER, O. A. A formação continuada de professores: ensino-pesquisa na escola: professores de química produzem seu programa de ensino e se constituem pesquisadores de sua pratica. 1997. 419f. Tese (doutorado em Educação) - Faculdade de Educação, UEC, Campinas, SP.

MICHA, D. N. Fotos da Lua pelo Mundo: um projeto observacional registrado em fotografia sobre como as fases da Lua se comparam quando observadas dos Hemisférios Norte e Sul. Revista Brasileira de Ensino de Física, v. 40, n. 3, p. e3310-1 - e3310-8, fev. 2018.

NÓVOA, A. Os professores e sua formação. Lisboa: Dom Quixote, p. 51-76, 1992.

OLIVEIRA, A. B.; MOREAU, A. D.; BARROS, V. P. O relato de um curso introdutório em astronomia para professores da rede pública da região de Itapetininga. In: SIMPÓSIO NACIONAL DE EDUCAÇÃO EM ASTRONOMIA, III, 2014, Curitiba. Atas... Paraná: 2014. p. 1-8. 
PEDRO, A. et al. Atividades práticas na formação continuada de professores de ciências: a construção de saberes docentes em uma relação entre universidade e escola básica. In: ENCONTRO NACIONAL DE PESQUISA EM EDUCAÇÃO EM CIÊNCIAS, X, 2015, Águas de Lindóia. Atas... São Paulo: 2015. p. 1-8.

PEREZ GÉMEZ, A. O pensamento prático do professor: a formação do professor como prático reflexivo. In: NÓVOA, A. Os professores e sua formação. Lisboa: Dom Quixote, 1992. p. 93-114.

PRADO, A. F; NARDI, R. Formação de professores dos anos iniciais e saberes docentes mobilizados durante um curso de formação em Astronomia. Revista Latino-Americana de Educação em Astronomia, n. 29, p. 103-116, 2020.

ROGÉRIO, T. P.; BISCH, S. M. Uma proposta de observação do céu. In: SIMPÓSIO NACIONAL DE EDUCAÇÃO EM ASTRONOMIA, V, 2018, Londrina. Atas... Londrina: 2018, p. 1-10.

SADLER, D. R. Formative assessment and the design of instructional systems. Instructional Science, v.18, p. 119-144, 1989.

SANZOVO, D. T.; GONÇALVES, M. L. C.; QUEIROZ, V.; LUCAS, L. B. Estratégias metodológicas para o ensino de astronomia em cursos de formação de professores nas publicações do SNEA e da RELEA. Revista Latino-Americana de Educação em Astronomia, n. 30, p. 65-82, 2020.

SPINA, F. A. Projetor celeste caseiro: uma atividade lúdica para ficar olhando para o céu. In: SIMPÓSIO NACIONAL DE EDUCAÇÃO EM ASTRONOMIA, V, 2018, Londrina. Atas... Londrina: 2018. p. 1.

SARAIVA, M. F. O.; SILVEIRA, F. L.; STEFFANI, M. H. Concepções de estudantes universitários sobre as fases da lua. Revista Latino-Americana de Educação em Astronomia, n.11, p. 63-80, 2011.

SCHON, A. D. Educando o profissional reflexivo: um novo design para o ensino e a aprendizagem. Porto Alegre: Artes Médicas, 2000.

SCHON, A. D. La formación de profesionales reflexivos: hacia um nuevo diseño de la enseñanza y el aprendizage em las profesiones. Barcelona: Paidós, 1992. 